\title{
ANALISIS PEMANFAATAN DANA BANTUAN OPERASIONAL SEKOLAH DI SMA DAN SMK
}

\section{ANALYSIS OF THE UTILIZATION OF SCHOOL OPERATIONAL ASSISTANCE IN GENERAL AND VOCATIONAL SENIOR HIGH SCHOOL}

\author{
Drs. Sudiyono, M.Pd. \\ Perekayasa pada Pusat Penelitian Pendidikan dan Kebudayaan, Balitbang, Kemendikbud \\ Jalan Jenderal Sudirman-Senayan, Jakarta \\ Diterima: 20 Mei 2017; dikembalikan untuk direvisi: 15 Jumi 2017; disetujui: 25 Juli 2017
}

\begin{abstract}
ABSTRAK
Abstrak. Tujuan penelitian ini adalah untuk mengkaji dana BOS di SMA dan SMK ditinjau dari sumber pendanaan, pemanfaatan dana, dan sebagai upaya peningkatan mutu pembelajaran. Studi ini merupakan penelitian deskriptif dengan pendekatan kuantitatif dan kualitatif. Populasi dalam studi ini adalah seluruh SMA/SMK yang menerima bantuan BOS tahun 2014 baik negeri maupun swasta di kabupaten/kota seluruh Indonesia. Teknik pengambilan sampel kabupaten/ kota menggunakan proporsional random sampling dengan didasarkan pada indeks kapasitas fiskal (IKF) tinggi dan rendah, sedangkan penentuan sampel SMA dan SMK secara random. Responden/sumber data penelitian adalah 64 kepala sekolah dan 64 pengelola BOS di sekolah sampel. Data dalam penelitian ini dikumpulkan dengan menggunakan kuesioner, FGD, dan dokumentasi. Data yang diperoleh dianalisis menggunakan metode statistik deskriptif. Hasil penelitian menunjukkan bahwa pemanfaatan dana BOS di SMA dan SMK terbesar digunakan untuk pengadaan buku dan kegiatan ekstrakurikuler efektif dalam membantu kegiatan kurikuler maupun ekstrakurikuler sehingga mampu meningkatkan mutu pembelajaran.
\end{abstract}

Kata kunci: BOS, Sekolah Menengah, Efektivitas

\section{ABSTRACT}

The purpose of this study is to examine the school operational assistance funds in general and vocational senior high school in terms of source of fund, utilization of fund and as an effort to improve the quality of learning. This study is descriptive research with quantitative and qualitative approach. The population in this study is the entire general and vocational senior high school which receive school operational assistance in 2014 both public and private in districts/cities throughout Indonesia. The sampling technique of districts/cities using proportional random sampling is based on high and low fiscal capacity index, whereas the determination of sample of general and vocational senior high school is random. Respondents/ research data sources were 64 school principals and 64 school operational assistance managers in sample schools. The data in this study were collected by using questionnaires, $F G D$, and documentation. The data obtained were analyzed using descriptive statistic method. The results showed that the utilization of school operational assistance funds in general and vocational senior high school is used to procure books and extracurricular activities and also effective in helping school activities such as curricular to enhance quality learning.

|Keywords: School Operational Assistance, High School, Effectivity 
Pemerintah terus berupaya meningkatkan kualitas sumber daya manusia melalui pendidikan. Berbagai kebijakan pendidikan telah dilaksanakan untuk menyelenggarakan pendidikan yang berkualitas. Salah satu kebijakan di bidang pendidikan adalah wajib belajar pendidikan dasar 9 tahun (Wajar Dikdas 9 tahun). Pelaksanaan Wajib belajar mengacu pada Undang-Undang Nomor 20, Tahun 2003 tentang Sistem Pendidikan Nasional (Pasal 34 (2)) (Republik Indonesia, 2003). Pemerintah dan pemerintah daerah menjamin terselenggaranya wajib belajar minimal pada jenjang pendidikan dasar tanpa memungut biaya. Pada ayat 3 disebutkan bahwa wajib belajar merupakan tanggung jawab negara yang diselenggarakan oleh lembaga pendidikan, Pemerintah, pemerintah daerah, dan masyarakat.

Program Wajar Dikdas 9 Tahun dicanangkan sejak Undang-Undang Nomor 20, Tahun 2003 tentang Sistem Pendidikan Nasional diundangkan telah mencapai target. Menurut data Badan Pusat Statistik (BPS), pada tahun 2003, angka partisipasi kasar (APK) SD/sederajat sebesar 105,82\%, meningkat hingga mencapai $108,87 \%$ pada tahun 2014. Untuk APK SMP/sederajat sebesar $81,09 \%$ pada tahun 2003 dan sebelas tahun kemudian sebesar 88,63\%. Setelah pencapaian target tersebut, pemerintah melakukan perluasan program dengan nama program Pendidikan Menengah Universal (PMU) dengan target APK untuk pendidikan menengah atau tingkat SMA/sederajat pada tahun 2020 sebesar 97\%. Sebagai gambaran pada tahun 2014 APK pendidikan menengah (SMA/sederajat) masih tertinggal di angka $74,26 \%$ (Badan Pusat Statistik, update 2017).
Untuk mencapai target tersebut pemerintah berkewajiban menyediakan akses seluas-luasnya dan berkeadilan bagi seluruh masyarakat termasuk lulusan SMP/sederajat agar dapat melanjutkan ke sekolah menengah. Salah satu perhatian pemerintah adalah meningkatkan kemampuan masyarakat untuk melanjutkan pendidikan ke jenjang menengah (SMA/sederajat). Untuk itu, pemerintah melaksanakan program Bantuan Operasional Sekolah di Sekolah Menengah (BOS SM).

Perluasan akses pendidikan menengah melalui program PMU menunjukkan keseriusan pemerintah dalam hal ini Kementerian Pendidikan dan Kebudayaan (Kemendikbud) dalam memanfaatkan momentum bonus demografi. Perluasan akses melalui PMU antara lain didukung dengan pemberian program BOS pada jenjang pendidikan menengah, yaitu di SMA dan SMK yang dimulai sejak bulan Juli 2013. Program BOS dinilai cukup efektif dalam mendukung program PMU (Cenik, et al 2014).

BOS SM ini adalah bantuan pemerintah pusat yang ditujukan untuk membantu sekolah, baik negeri maupun swasta, dalam memenuhi biaya operasional sekolah khususnya nonpersonalia serta menjamin keberpihakan pemerintah bagi siswa miskin. BOS SM bertujuan: (i) membantu biaya operasional sekolah; (ii) mengurangi angka putus sekolah; (iii) meningkatkan APK siswa; (iv) mewujudkan keberpihakan pemerintah (affirmative action) bagi siswa miskin melalui pembebasan (fee waive) dan/ atau membantu (discount fee) tagihan biaya sekolah bagi siswa miskin; (v) memberikan kesempatan yang setara (equal opportunity) bagi siswa miskin untuk mendapatkan layanan 
pendidikan yang terjangkau dan bermutu dan meningkatkan kualitas proses pembelajaran di sekolah (Kementerian Pendidikan dan Kebudayaan, 2014).

Hasil penelitian BOS dinilai cukup efektif dalam membantu biaya operasional sekolah khususnya dalam kegiatan sekolah baik kegiatan kurikuler maupun kegiatan ekstrakurikuler. BOS juga dinilai efektif dalam meningkatkan mutu pembelajaran (Kurniasari dkk. 2015).

Pemberian dana BOS dalam membantu biaya operasional sekolah telah banyak dirasakan manfaatnya oleh masyarakat, tetapi bukan berarti bantuan dana BOS tanpa permasalahan. Jika dicermati berbagai hasil penelitian dan pemberitaan media masa masih terdapat beberapa permasalahan terkait dengan dana BOS seperti pemanfaatan dana BOS belum sesuai juknis dan dampak program yang belum diketahui (Kementerian Pendidikan dan Kebudayaan, 2014). Dana BOS juga masih banyak disalahgunakan dalam pemanfaatannya yang tidak sesuai dengan petunjuk teknis. Hal ini sebagai mana terjadi di Kabupaten Garut dana BOS digunakan untuk kegiatan O2SN yang menyalahi peruntukannya. Penyalahgunaan dana BOS juga terjadi di SMPN 2 Bontocani, Bone, Sulawesi Selatan, dan SMA Sanur Balibo, Kecamatan Kindang, Bulukumba (Ferdiansyah, 2013).

Banyaknyapermasalahanpemanfaatan dana BOS ini karena pengelola dana BOS di sekolah umumnya tidak memahami petunjuk teknis pemanfaatan dana BOS, sehingga banyak terjadi kesalahan dalam pertanggungjawabannya (Jayatri, 2012).

Melihat kondisi tersebut kiranya perlu dikaji pengelolaan dana BOS pada pendidikan menengah khususnya di SMA dan SMK dalam aspek kontribusi BOS dalam pendanaan sekolah, pemanfaatan dana, dan peningkatan mutu pembelajaran. Selanjutnya, perlu dikaji pula peran pemerintah daerah dalam mendukung pendanaan pendidikan menengah khususnya SMA dan SMK.

Berkaitan hal tersebut tujuan penelitian ini secara umum untuk mendapatkan rekomendasi kebijakan terkait dengan sumber pendanaan dan pemanfaatan dana BOS di SMA dan SMK. Secara khusus tujuan penelitian ini untuk mendapatkan informasi tentang pelaksanaan program BOS di SMA dan SMK yang meliputi sumber pendanaan, pemanfaatan dana BOS, dan peningkatan mutu pendidikan.

\section{KAJIAN PUSTAKA \\ Konsep BOS}

BOS adalah program Pemerintah berupa pemberian dana langsung ke sekolah baik Negeri maupun Swasta untuk membantu biaya operasional sekolah nonpersonalia sebagai pelaksana program wajib belajar. Besar dana bantuan yang diterima sekolah dihitung berdasarkan jumlah siswa masingmasing sekolah dikalikan satuan biaya (unit cost) bantuan. Menurut Peraturan Pemerintah Nomor 48, Tahun 2008 (PP 48/2008) tentang Pendanaan Pendidikan, biaya nonpersonalia adalah biaya untuk bahan atau peralatan pendidikan habis pakai, dan biaya tak langsung berupa daya, air, jasa telekomunikasi, pemeliharaan sarana dan prasarana, uang lembur, transportasi, konsumsi, pajak dll. Namun, ada beberapa jenis pembiayaan investasi dan personalia yang diperbolehkan dibiayai dengan dana BOS (Republik Indonesia, 2008). 
Berdasarkan definisi tersebut maka BOS pada dasarnya merupakan komponen pembiayaan operasional nonpersonil, bukan ditujukan untuk pembiayaan kesejahteraan guru. Secara umum, komponen utama pembiayaan BOS adalah biaya satuan pendidikan (BSP). BSP merupakan biaya yang diperlukan rata-rata tiap siswa setiap tahun sehingga dapat menunjang kegiatan pembelajaran sesuai dengan standar pelayanan yang ditetapkan. Dalam penggunaannya, BSP dibedakan menjadi BSP investasi dan BSP operasional. BSP investasi merupakan biaya yang dikeluarkan per siswa per tahun untuk menyediakan sumber daya yang tidak habis pakai yang digunakan dalam waktu lebih dari satu tahun. Contohnya adalah pengadaan tanah, bangunan, buku, alat peraga, perabot dan alat kantor, sedangkan BSP operasional merupakan besarnya biaya yang dikeluarkan per siswa per tahun yang habis pakai digunakan satu tahun atau kurang.

BSP operasional menurut Peraturan Kementerian Pendidikan Nasional Nomor 69, Tahun 2009 mencakup biaya personil dan nonpersonil (Kementerian Pendidikan Nasional, 2009). Biaya personil meliputi gaji tenaga pendidik dan tenaga kependidikan serta tunjangan yang melekat pada gaji seperti: kesejahteraan honor kelebihan jam mengajar (KJM), guru tidak tetap (GTT), pegawai tidak tetap (PTT), uang lembur, pengembangan profesional (Diklat), Kelompok Kerja Guru (KKG), Kelompok Kerja Kepala Sekolah (K3S) dan sebagainya. Biaya nonpersonil adalah biaya untuk penunjang proses pengajaran dan pembelajaran (KBM), evaluasi/penilaian, perawatan-pemeliharaan, daya dan jasa, pembinaan kesiswaan, rumah tangga sekolah dan supervisi (Kementerian Pendidikan Nasional, 2009).

Standar biaya operasi nonpersonalia adalah standar biaya yang diperlukan untuk membiayai kegiatan operasi nonpersonalia selama satu tahun sebagai bagian dari keseluruhan dana pendidikan agar satuan pendidikan dapat melakukan kegiatan pendidikan secara teratur dan berkelanjutan (Kementerian Pendidikan Nasional, 2009).

BOS adalah program pemerintah yang pada awalnya adalah untuk penyediaan pendanaan biaya operasi nonpersonalia bagi satuan pendidikan dasar sebagai pelaksana program wajib belajar. Selanjutnya, pada tahun 2013 dikembangkan pada pendidikan menengah.

Tujuan program BOS untuk mewujudkan layanan pendidikan yang terjangkau dan bermutu bagi masyarakat. Secara khusus program BOS bertujuan untuk: membantu biaya operasional sekolah; mengurangi angka putus sekolah; meningkatkan APK; mewujudkan keberpihakan pemerintah (affirmative action) terhadap siswa sekolah dengan cara meringankan biaya sekolah; memberikan kesempatan yang setara (equal opportunity) bagi siswa miskin SMA untuk mendapatkan layanan pendidikan yang terjangkau dan bermutu (khusus SMA); dan meningkatkan kualitas proses pembelajaran di sekolah (khusus SMA).

\section{Efektivitas}

Efektivitas selalu berkaitan hubungannya antara hasil yang diharapkan dengan hasil yang telah dicapai. Efektivitas dapat dilihat dari berbagai sudut pandang dan dapat dinilai dengan berbagai cara dan mempunyai kaitan yang erat dengan efisiensi. Efektivitas dimaknai sebagai 
tingkat keberhasilan organisasi dalam usaha untuk mencapai tujuan dan sasaran (Etzioni, dkk dalam Hamzah, 2013). Sementara definisi lainnya tentang efektivitas adalah suatu keadaan yang menunjukkan tingkatan keberhasilan manajemen dalam mencapai tujuan yang telah ditetapkan terlebih dahulu (Komaruddin,1994). Pada dasarnya dalam memaknai efektivitas setiap orang dapat memberi arti yang berbeda sesuai sudut pandang dan kepentingan masing-masing.

Efektivitas merupakan unsur pokok untuk mencapai tujuan yang telah ditentukan di dalam suatu program kegiatan. Suatu program dikatakan efektif apabila tujuan tercapai sesuai dengan rencana yang telah ditentukan. Efektivitas ditinjau dari sudut pencapaian tujuan, bahwa untuk mencapai keberhasilan suatu organisasi perlu mempertimbangkan sasaran dan mempertahankan diri dalam mengejar sasaran. Dapat dikatakan, penilaian efektivitas harus berkaitan dengan sasaran maupun tujuan. Selanjutnya, Steers mengemukakan bahwa efektivitas adalah jangkauan usaha suatu program sebagai suatu sistem dengan sumber daya dan sarana tertentu untuk memenuhi tujuan dan sasarannya tanpa melumpuhkan cara dan sumber daya itu serta tanpa memberi tekanan yang tidak wajar terhadap pelaksanaannya (Steers, 1985). Definisi lain tentang efektivitas adalah kemampuan melaksanakan tugas dan fungsi pada suatu organisasi tidak adanya tekanan atau ketegangan di antara pelaksanaannya (Kurniawan, 2005).

Dari beberapa pendapat di atas dapat disimpulkan bahwa efektivitas adalah suatu ukuran yang menyatakan seberapa jauh target (kuantitas, kualitas dan waktu) yang telah dicapai oleh manajemen, yang mana target tersebut sudah ditentukan terlebih dahulu. Hal ini sesuai dengan pendapat yang dikemukakan oleh Hidayat (1986) yang menjelaskan bahwa "Efektivitas adalah suatu ukuran yang menyatakan seberapa jauh target (kuantitas, kualitas dan waktu) telah tercapai, yang mana makin besar persentase target yang dicapai, makin tinggi efektivitasnya".

Kegiatan mengevaluasi jalannya suatu organisasi, dapat dilakukan melalui konsep efektivitas. Konsep ini adalah salah satu faktor untuk menentukan apakah perlu dilakukan perubahan secara signifikan terhadap bentuk dan manajemen organisasi atau tidak. Dalam hal ini efektivitas merupakan pencapaian tujuan organisasi melalui pemanfaatan sumber daya yang dimiliki secara efisien, ditinjau dari sisi masukan (input), proses, maupun keluaran (output). Sumber daya yang dimaksudkan di sini meliputi ketersediaan personil, sarana dan prasarana serta metode dan model yang digunakan. Suatu kegiatan dikatakan efisien apabila dikerjakan dengan benar dan sesuai dengan prosedur sedangkan dikatakan efektif apabila kegiatan tersebut dilaksanakan dengan benar dan memberikan hasil yang bermanfaat.

\section{Ukuran Efektivitas}

Mengukur efektivitas suatu program dapat dilihat dari berbagai dimensi tergantung siapa yang menilai serta menginterpretasikannya. Tingkat efektivitas juga dapat diukur dengan membandingkan antara rencana yang telah ditentukan dengan hasil nyata yang telah diwujudkan. Namun, jika usaha atau hasil pekerjaan dan tindakan yang dilakukan tidak tepat sehingga menyebabkan tujuan tidak tercapai atau sasaran yang diharapkan maka hal itu dikatakan tidak efektif. Kriteria atau 
ukuran tingkat efektivitas dalam mencapai tujuan ada delapan, yaitu (a) kejelasan tujuan yang hendak dicapai, hal ini dimaksudkan supaya karyawan dalam pelaksanaan tugas mencapai sasaran yang terarah dan tujuan organisasi dapat tercapai; (b) kejelasan strategi pencapaian tujuan, telah diketahui bahwa strategi adalah "pada jalan" yang diikuti dalam melakukan berbagai upaya dalam mencapai sasaran-sasaran yang ditentukan agar para implementer tidak tersesat dalam pencapaian tujuan organisasi; (c) proses analisis dan perumusan kebijakan yang mantap, berkaitan dengan tujuan yang hendak dicapai dan strategi yang telah ditetapkan, artinya kebijakan harus mampu menjembatani tujuan-tujuan dengan usahausaha pelaksanaan kegiatan operasional; (d) perencanaan yang matang, pada hakikatnya berarti memutuskan sekarang apa yang dikerjakan oleh organisasi di masa depan; (e) penyusunan program yang tepat suatu rencana yang baik masih perlu dijabarkan dalam program-program pelaksanaan yang tepat sebab apabila tidak, para pelaksana akan kurang memiliki pedoman bertindak dan bekerja; (f) tersedianya sarana dan prasarana kerja, salah satu indikator efektivitas organisasi adalah kemampuan bekerja secara produktif dengan sarana dan prasarana yang tersedia dan mungkin disediakan oleh organisasi; (g) pelaksanaan yang efektif dan efisien, bagaimana pun baiknya suatu program apabila tidak dilaksanakan secara efektif dan efisien maka organisasi tersebut tidak akan mencapai sasarannya, karena dengan pelaksanaan organisasi semakin didekatkan pada tujuannya; dan (h) sistem pengawasan dan pengendalian yang bersifat mendidik mengingat sifat manusia yang tidak sempurna maka efektivitas organisasi menuntut terdapatnya sistem pengawasan dan pengendalian (Siagian, 2001).

Adapun kriteria untuk mengukur efektivitas suatu organisasi ada tiga pendekatan (Martani dan Lubis, 1987), yaitu (i) pendekatan sumber (resource approach) yang mengukur efektivitas dari input, pendekatan mengutamakan adanya keberhasilan organisasi untuk memperoleh sumber daya, baik fisik maupun nonfisik yang sesuai dengan kebutuhan organisasi; (ii) pendekatan proses (process approach) adalah untuk melihat sejauh mana efektivitas pelaksanaan program dari semua kegiatan proses internal atau mekanisme organisasi; (iii) pendekatan sasaran (goals approach) di mana pusat perhatian pada output, mengukur keberhasilan organisasi untuk mencapai hasil (output) yang sesuai dengan rencana.

Duncan yang dikutip Steers (1985) dalam bukunya "Efektivitas Organisasi" mengatakan mengenai ukuran efektivitas ada tiga. Pertama, pencapaian tujuan adalah keseluruhan upaya dalam mencapai tujuan yang dipandang sebagai suatu proses. Oleh karena itu, agar pencapaian tujuan akhir semakin terjamin, diperlukan pentahapan, baik dalam arti pentahapan pencapaian bagian-bagiannya maupun pentahapan dalam arti periodenya. Pencapaian tujuan terdiri dari beberapa faktor, yaitu kurun waktu dan sasaran yang merupakan target kongkrit. Kedua, integrasi yaitu pengukuran terhadap tingkat kemampuan suatu organisasi untuk mengadakan sosialisasi, pengembangan konsensus dan komunikasi dengan berbagai macam organisasi lainnya. Integrasi menyangkut proses sosialisasi. Ketiga, adaptasi adalah kemampuan organisasi untuk 
menyesuaikan diri dengan lingkungannya. Untuk itu, digunakan tolak ukur proses pengadaan dan pengisian tenaga kerja.

Terdapat tiga penelitian tentang efektivitas program BOS telah dilakukan lima tahun terakhir. Laporan Kajian Efektivitas Pemberian Dana BOS Tingkat SD dan SMP Negeri di Kota Medan Tahun Anggaran 2012, oleh Balitbang Kota Medan (2012) menunjukkan bahwa belum semua sekolah menyalurkan dana BOS sesuai dengan ketentuan yang tercantum dalam Juknis BOS 2012; dana BOS SD paling banyak digunakan untuk a) pembelian buku teks, b) perawatan sekolah, c) pembelian bahan habis pakai, dan d) pembayaran guru dan pegawai honor; dana BOS SMP paling banyak digunakan untuk: a) pembelajaran dan ekstrakurikuler, b) pengembangan profesi guru, c) kegiatan ulangan dan ujian, dan d) perawatan sekolah; dampak dana BOS terhadap kinerja sekolah belum menunjukkan hasil yang signifikan. Selanjutnya, hasil penelitian Analisis Efektivitas, Akuntabilitas dan Transparansi Bantuan Operasional Sekolah pada Sekolah Menengah Pertama di Kota Padang (Erwantosi, 2010) diketahui bahwa penggunaan dana BOS sebagian besar hanya terserap untuk pembayaran honorarium guru dan pegawai. Akuntabilitas dan transparansi dalam pengelolaan dana BOS masih sangat lemah dan belum memadai, hal ini disebabkan dalam penggunaan dana BOS tidak banyak melibatkan guru dan komite sekolah sebagai alat kontrol dalam perencanaan maupun dalam penggunaan dana. Hasil penelitian terkait berikutnya tentang Efektivitas Manajemen Dana Bantuan Operasional Sekolah dalam Meningkatkan Mutu Pendidikan (Studi Kasus Pengelolaan Dana BOS di SDN Pacarkeling
1 Surabaya) yang dilakukan oleh Waluyo dkk (2012) dapat disimpulkan bahwa efektivitas manajemen dana BOS dalam meningkatkan mutu pendidikan sudah dapat mewujudkan tujuan utama dari pengelolaan dana BOS, yaitu program dana BOS yang dihasilkan telah tepat sasaran, peningkatan kompetensi siswa dan kualitas belajar dan bertambahnya tenaga pendidik dalam membantu kegiatan belajar mengajar.

\section{METODE PENELITIAN}

Metode penelitian yang digunakan adalah survei dan merupakan penelitian deskriptif dengan menggunakan pendekatan kuantitatif dan kualitatif.

Populasi dalam studi ini adalah seluruh SMA/SMK yang menerima bantuan BOS tahun 2014 baik negeri maupun swasta di kabupaten/kota seluruh Indonesia. Teknik pengambilan sampel kabupaten/kota menggunakan proporsional random sampling dengan didasarkan pada indeks kapasitas fiskal (IKF) tinggi dan rendah yang diperoleh dari Peraturan Menteri Keuangan RI Nomor 54/PMK.07/2014 tentang Peta Kapasitas Fiskal Daerah. IKF adalah gambaran kemampuan keuangan masing-masing daerah yang dicerminkan melalui penerimaan umum Anggaran Pendapatan dan Belanja Daerah (tidak termasuk dana alokasi khusus, dana darurat, dana pinjaman lama, dan penerimaan lain yang penggunaannya dibatasi untuk membiayai pengeluaran tertentu) untuk membiayai tugas pemerintahan setelah dikurangi belanja pegawai dan dikaitkan dengan jumlah penduduk miskin (Kementerian Keuangan, 2014).

Penelitian dilaksanakan pada tahun 2015 di delapan kabupaten/kota, yaitu Kota 
Samarinda, Kota Jayapura, Kota Manado, Kota Salatiga, Kabupaten Deli Serdang, Kabupaten Bogor, Kabupaten Banyuwangi, dan Kabupaten Gunung Kidul. Jumlah sampel SMA/SMK sebanyak 128 sekolah.

Variabel yang digunakan dalam penelitian ini adalah sesuai dengan tujuan penelitian yaitu variabel-variabel yang terkait dengan pemanfaatan BOS dalam membantu biaya operasional sekolah, mengurangi angka putus sekolah, dan meningkatkan pembelajaran di sekolah. Pengumpulan data menggunakan kuesioner, dan focus group discussion (FGD), dan studi dokumentasi. Kuesioner dan FGD digunakan untuk memperoleh data dan informasi terkait dengan pemanfaatan BOS di SMA dan SMK tahun 2014 sebagai upaya mengurangi angka putus sekolah dan peningkatan mutu pendidikan. Untuk mendalami dan menjelaskan tingkat manfaat program BOS digunakan data kualitatif yang diperoleh dari FGD. Data kualitatif berupa informasi dalam bentuk persepsi/pandangan informan tentang bagaimana BOS dapat berpengaruh terhadap angka putus sekolah dan peningkatan pembelajaran di SMA dan SMK.

Kuesioner ditujukan kepada dinas pendidikan dan satuan pendidikan. FGD ditujukan kepada kepala sekolah untuk mengetahuibagaimana persepsi atau pandangan kepala sekolah tentang efektivitas program BOS jenjang Dikmen tahun 2014 dan mencari jawaban mengapa hal tersebut dapat terjadi. Studi dokumentasi untuk mengetahui anggaran pendidikan di tingkat satuan pendidikan khususnya biaya operasional nonpersonalia.

Teknik analisis data kuantitatif dilakukan menggunakan statistik deskriptif. Data kualitatif, hasil FGD diklasifikasikan berdasarkan pertanyaan penelitian dan informan yang memberikan penjelasan atau pendapat.

\section{HASIL PENELITIAN}

Pemanfaatan dana BOS periode tahun 2013/2014 dan 2014/2015 sedikitnya masih ditemukan beberapa kendala, di antaranya adalah masih terdapat sekolah-sekolah yang belum memahami penggunaan dana BOS yang sudah ditetapkan dalam panduan. Indikasinya pemanfaatan dana BOS terbesar cenderung hanya terkonsentrasi pada poin tertentu saja, yang terkesan sekolah memaksakan.

Kekurangpahaman penggunaan dana ini dipengaruhi oleh dua hal, yakni keterlambatan penerimaan panduan oleh sekolah dan kekurangjelasan panduan menurut pihak sekolah. Keterlambatan ini cenderung terjadi pada sekolah-sekolah yang berada di pinggiran dan di luar ibukota kabupaten. Kekurangpahaman yang terjadi antara lain adalah pada pemanfaatan dana untuk pengadaan sarana pembelajaran (LCD, laptop) dan pembayaran pajak.

Secara lebih lengkap berikut disampaikan pembahasan ketersediaan sumber dana dan pemanfaatan dana BOS di SMA dan SMK.

\section{Sumber Pendanaan di SMA dan SMK}

Sumber pendanaan yang digunakan di SMA dan SMK untuk memenuhi biaya operasional sekolah terdapat tiga jenis sumber dana, yakni dari Pemerintah (pusat), pemerintah daerah (provinsi dan kabupaten/ kota) dan dari masyarakat (orang tua siswa). Dana dari pemerintah (pusat) antara lain adalah; BOS, Dana Alokasi Khusus (DAK), dan Bantuan Siswa Miskin (BSM), atau nama lainnya. Dari pemerintah daerah ada dua sumber, yaitu dariprovinsi dan darikabupaten/ 
kota dengan nama yang bervariasi sesuai dengan isu di daerah masing-masing, untuk memudahkan analisis diberi nama bos daerah (BOSDa). Biaya dari masyarakat utamanya dari orang tua siswa dalam berbentuk iuran komite (SPP) atau iuran gedung dan dana dari sumber-sumber lainnya. jenis dan status sekolah menengah yang ada, kontribusi BOS Pusat terbesar terjadi pada SMK swasta, yakni sebesar 36,4 persen dari seluruh penerimaan sekolah. Kontribusi BOS Pusat pada ketiga jenis sekolah lainnya berkisar dari 29,6 sampai 31,1 persen.

Kontributor terbesar pembiayaan

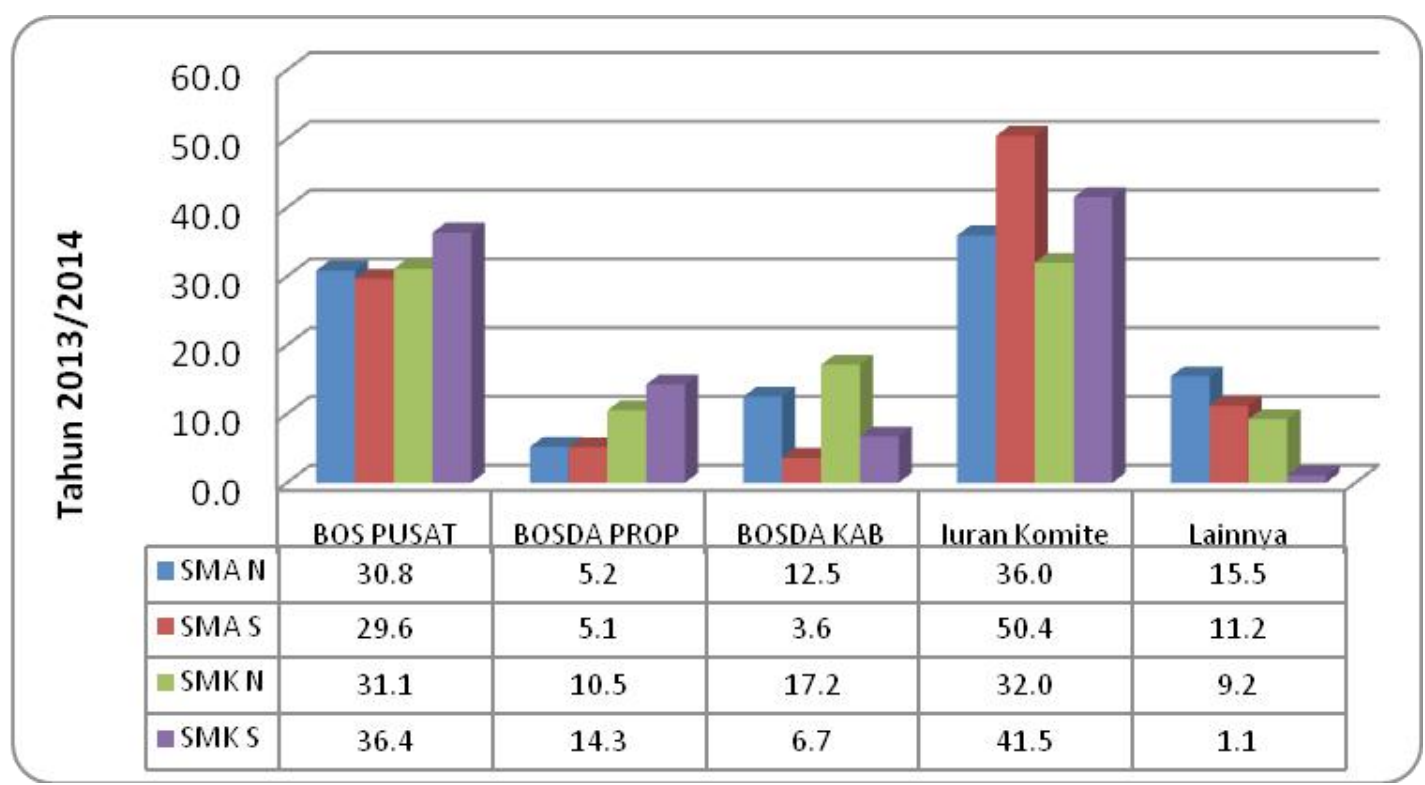

Grafik 1, Sumber Dana dan Pembiayaan Operasional Sekolah SMAN/S dan SMKN/S Tahun 2013/2014

Biaya operasional SMA dan SMK baik negeri maupun swasta tahun ajaran 2013/2014 sumber dana terbesar diperoleh dari iuran komite dan BOS Pusat (Grafik 1). Sumber-sumber lainnya sebagai pendukung operasional sekolah adalah bantuan dari pemerintah provinsi dan kabupaten/kota dengan nama BOSDa atau nama lainnya, dan sumber lain-lain relatif lebih kecil dibanding dengan kedua sumber utama tersebut.

Analisis komposisi sumber pembiayaan operasional sekolah tahun 2013/2014 mengindikasikan bahwa, walaupun bukan kontributor terbesar, kontribusi BOS sangat membantu dalam pembiayaan kegiatan operasional sekolah. Di antara keempat operasional sekolah adalah dari iuran komite. Iuran komite menjadi sumber dana terbesar pada SMA swasta, yaitu mencapai 50,4 persen. Iuran komite cenderung menjadi sumber dana terbesar di sekolah swasta jika dibandingkan dengan sekolah negeri. Lain halnya dengan SMK dana BOS di SMK swasta cukup besar, yaitu sebesar 41,5 persen, lebih besar jika dibandingkan dengan SMA negeri sebesar 36,0 persen dan SMK negeri sebesar 32,0 persen.

Kontribusi pemerintah kabupaten/ kota lebih kecil jika dibandingkan dengan pemerintah pusat walaupun sudah otonomi daerah namun lebih besar jika dibandingkan dengan pemerintah provinsi. Sumbangan dana 
pendidikan terbesar pemda kabupaten/kota terjadi untuk SMK negeri, yaitu mencapai 17,2 persen. Kontribusi pemda kabupaten/ kota ini cenderung lebih besar pada sekolah negeri jika dibandingkan dengan pada sekolah swasta. Kontribusi ke SMA dan SMK negeri masing-masing sebesar 12,5 persen dan 17,2 persen, sedangkan kontribusi ke SMK dan SMA swasta masing-masing sebesar 3,6 dan 6,7 persen.

Sumber dana berikutnya adalah sumber lain-lain, termasuk di dalamnya sumbangan dari orang tua yang diserahkan langsung ke sekolah dan sumbangan dari dunia usaha dan industri. Kontribusi terbesar sumber-sumber lainnya terjadi pada SMA negeri sebesar 15,5 persen. Kontribusi sumber-sumber lainnya ini cenderung lebih besar ke SMA jika dibandingkan dengan SMK. Kontribusi ke SMA negeri dan swasta masing-masing sebesar 15,5 persen dan 11,2 persen, sedangkan kontribusi ke SMK negeri dan swasta masingmasing sebesar 9,2 dan 1,1 persen.
Bantuan dana pendidikan untuk SMA/ SMK terkecil dari BOSDa provinsi terkecil adalah SMA Swasta sebesar 5,1 persen. Bantuan dana terbesar dari provinsi untuk SMK swasta, yaitu mencapai 14,3 persen. Kontribusi dana dari provinsi ini cenderung lebih besar diberikan pada SMK jika dibandingkan dengan SMA, karena di SMK lebih banyak memerlukan biaya khususnya untuk kegiatan praktik siswa.

Sementara itu, untuk pembiayaan operasional SMA/SMK negeri/swasta tahun ajaran 2014/2015, tidak ada perbedaan yang signifikan dengan tahun sebelumnya, sumber dana terbesar masih diperoleh dari iuran komite dan BOS Pusat (Grafik 2). Namun, terjadi urutan proporsi besarnya kontribusi dari ketiga sumber pembiayaan operasional sekolah di luar kedua sumber utama tersebut. Kontributor ketiga terbesar adalah sumber-sumber lainnya, sedangkan BOSDa kabupaten/kota atau nama lain yang sejenis merupakan kontributor terbesar keempat dan

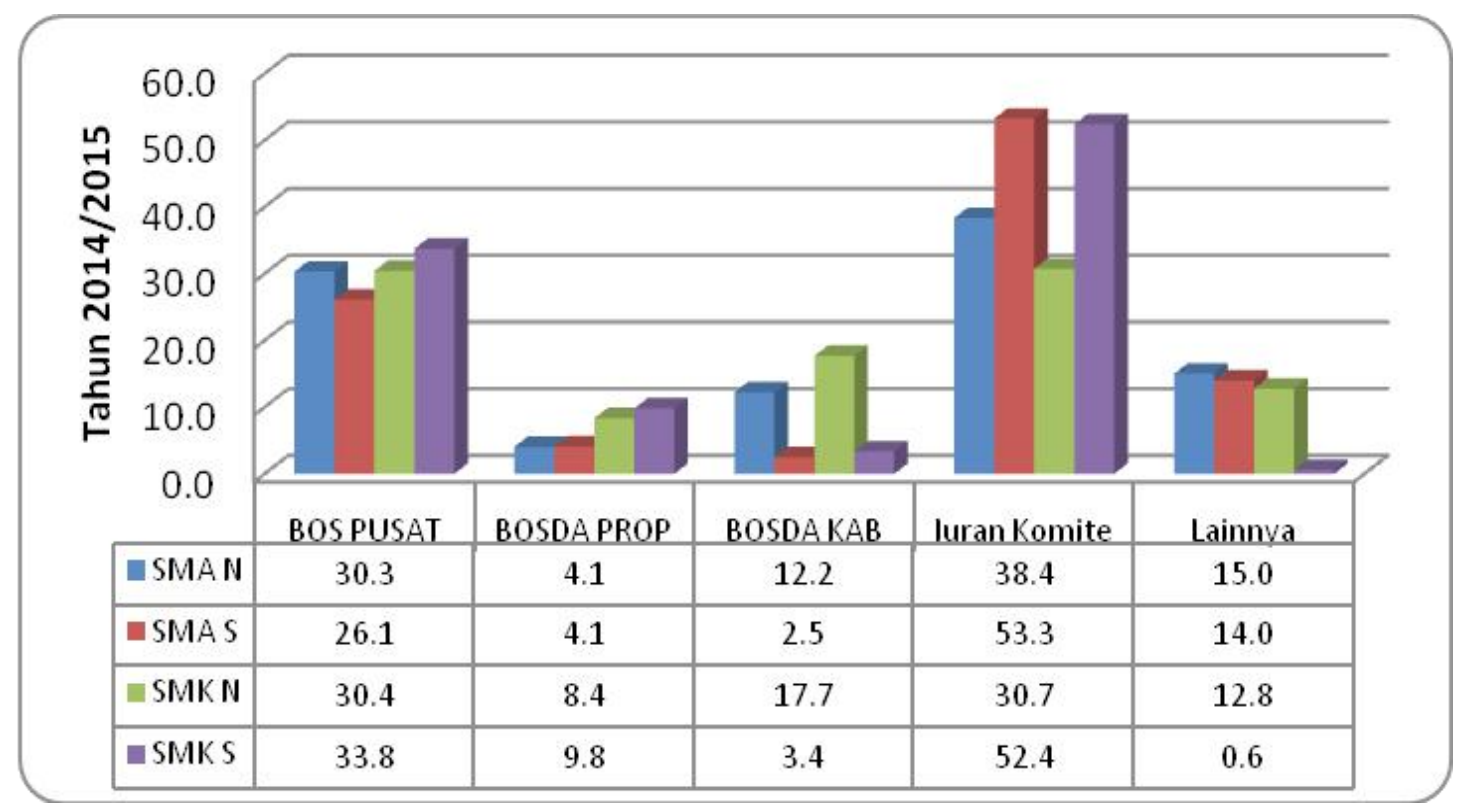

Grafik 2, Sumber Dana Sekolah untuk Pembiayaan Operasional Sekolah SMAN/S dan SMKN/S Tahun 2014/2015 
kontributor terkecil tetap BOSDa provinsi atau nama lain yang sejenis.

Dana BOS Pusat tahun 2014/2015 masih merupakan sumber dana terbesar kedua dalam pembiayaan kegiatan operasional sekolah. Dana BOS Pusat menjadi andalan pembiayaan operasional di SMKS dengan proporsi kontribusi sebesar 33,8 persen. Kontribusi BOS Pusat pada ketiga jenis dan status sekolah lainnya berkisar dari 26,1 persen sampai 30,4 persen. Kontribusi BOS terhadap pembiayaan operasional sekolah tahun 2014/2015 agak lebih rendah jika dibandingkan dengan tahun sebelumnya, kecuali BOSDa Kabupaten untuk SMKN dan Lainnya untuk SMAS dan SMKN. Penurunan kontribusi BOS pada situasi ketika besarnya dana BOS meningkat mengindikasikan adanya peningkatan biaya operasional sekolah yang lebih tinggi jika dibandingkan dengan peningkatan BOS (Grafik 1 dan Grafik 2).

Dana operasional terbesar untuk SMAS/ SMKS pada tahun 2014/2015 masih mengandalkan dari iuran komite sekolah. Dana dari iuran komite sekolah ini memenuhi kebutuhan sekolah masing-masing mencapai 53,3 persen pada SMAS dan 52,4 persen pada SMKS. Kontribusi iuran komite sekolah ini, sebagaimana juga terjadi pada tahun sebelumnya, cenderung lebih besar ke sekolah swasta jika dibandingkan dengan ke sekolah negeri. Lebih besarnya kontribusi pada sekolah swasta ini terjadi karena biaya operasional personalia (yaitu gaji pendidik dan tenaga kependidikan) pada sekolah swasta tidak ditanggung oleh Pemerintah sebagaimana diberlakukan oleh Pemerintah kepada sekolah negeri dengan anggaran di luar BOS.
Kontribusi iuran komite sekolah terhadap pembiayaan operasional sekolah tahun 2014/2015 agak lebih tinggi jika dibandingkan dengan tahun sebelumnya. Peningkatan kontribusi yang terjadi ketika besarnya dana BOS per siswa meningkat ini mengindikasikan meningkatnya biaya operasional sekolah dan peningkatan itu dikompensasi oleh iuran komite sekolah yang lebih besar.

Kontributor ketiga terbesar terhadap pembiayaan operasional sekolah tahun 2014/2015 adalah sumber-sumber lain dengan proporsi kontribusi terhadap pembiayaan operasional sekolah yang juga meningkat. Kontribusi sumber biaya ini terhadap pembiayaan operasional SMA negeri dan swasta serta SMK negeri berkisar dari 15,0 dan 14,0 persen sampai 12,8 persen, dan kontribusi terkecil di SMK swasta yang hanya sebesar 0,6 persen dari jumlah pembiayaan operasional sekolah.

Sementara itu, dana yang bersumber dari BOSDa Provinsi dan BOSDa Kabupaten/kota yang masing-masing proporsi kontribusinya kecil. Namun, apabila keduanya digabung kontribusinya menjadi melebihi sumbersumber lain. Karakteristik kontribusi kedua pemda ini pada pembiayaan operasional sekolah tahun 2014/2015, baik di SMA negeri/swasta maupun SMK negeri/swasta cenderung lebih kecil jika dibandingkan dengan tahun 2013/2014.

Sumber Pembiayaan Operasional Sekolah SMA dan SMK di Kabupaten/Kota sampel

Komposisi pembiayaan operasional di SMA dan SMK tahun 2013/2014 di kabupaten/kota sampel sangat beragam, namun secara umum masih mengandalkan dana iuran komite dan dana BOS. 
Proporsi pendanaan terbesar antara kabupaten/kota yang satu dengan lainnya bervariasi, namun iuran komite sekolah memiliki proporsi pembiayaan operasional sekolah terbesar pada separuh kabupaten/ kota yang menjadi sampel, bahkan pada tiga kabupaten/kota (Kabupaten Bogor, Kota Manado, dan Kota Salatiga) atau 37,5 persen dari kabupaten/kota sampel, iuran komite sekolah memiliki kontribusi lebih dari 50 persen pembiayaan operasional sekolah pada tahun 2013/2014. Kontribusi tersebut berkisar dari antara 12,19 persen (Kota Samarinda) sampai setinggi 63,08 persen (Kota Salatiga) dari seluruh pembiayaan operasional sekolah.

Selanjutnya, BOS pusat mendominasi pembiayaan operasional sekolah pada tiga kabupaten/kota atau 37,5 persen dari kabupaten/kota sampel, dengan dua kabupaten/kota (Kabupaten Jayapura dan Banyuwangi) di antaranya memiliki kontribusi lebih dari 50 persen. Kontribusi sumber pembiayaan operasional ini berkisar dari 23,10 persen (Kabupaten Gunung Kidul) sampai 51,45 persen (Kabupaten Jayapura) dari seluruh pembiayaan operasional sekolah.

BOSDa kabupaten/kota juga memiliki kontribusi terbesar dalam pembiayaan operasional sekolah namun hanya di satu (Kabupaten Deli Serdang) dari delapan kabupaten/kota. Kontribusi tersebut besarnya adalah 34,13 persen pada tahun 2013/2014 dan 38,18 persen pada tahun 2014/2015 dari seluruh nilai pembiayaan operasional sekolah.

Selain kontribusi terbesar, terdapat fenomena yang mengejutkan, yaitu adanya kabupaten/kota dan provinsi yang tidak memiliki kontribusi secara rutin sama sekali terhadap pembiayaan operasional sekolah menengah di daerahnya. Pemda di tiga per delapan kabupaten/kota (Kabupaten Bogor, Kota Manado, dan Kota Salatiga) dari seluruh kabupaten/kota tidak memiliki kontribusi secara rutin dalam pendidikan menengah di daerahnya. Demikian juga pemda di tiga per delapan dari seluruh provinsi (Kabupaten Deli Serdang, Kota Salatiga, dan Kabupaten Banyuwangi) tidak memiliki kontribusi secara rutin dalam pendidikan di daerahnya. Selain itu, terdapat seperempat dari seluruh provinsi sampel (Kabupaten Jayapura dan Kota Manado) hanya memiliki kontribusi rutin namun sangat kecil, yaitu 0,70 persen dan 1,58 persen dari seluruh pembiayaan operasional sekolah menengah.

\section{Tabel 1}

Sumber Pembiayaan di SMA dan SMK Tahun Ajaran 2013/2014 (dalam persen)

\begin{tabular}{|r|l|r|r|r|r|}
\hline No & Kabupaten/Kota & $\begin{array}{c}\text { BOS } \\
\text { Pusat }\end{array}$ & $\begin{array}{c}\text { BOS } \\
\text { Provinsi }\end{array}$ & \multicolumn{1}{c|}{$\begin{array}{c}\text { BOS } \\
\text { Kabupaten/Kota }\end{array}$} & Iuran Komite \\
\hline 1 & Kab. Bogor & 33,21 & 11,46 & 0,00 & 55,34 \\
\hline 2 & Kab. Deli Serdang & 43,08 & 0,00 & 34,13 & 22,79 \\
\hline 3 & Kab. Gunung Kidul & 23,10 & 10,42 & 26,26 & 40,22 \\
\hline 4 & Kab. Jayapura & 51,45 & 0,70 & 18,22 & 29,63 \\
\hline 5 & Kota Manado & 37,50 & 1,58 & 0,00 & 60,91 \\
\hline 6 & Kota Salatiga & 36,92 & 0,00 & 0,00 & 63,08 \\
\hline 7 & Kota Samarinda & 29,26 & 37,54 & 21,01 & 12,19 \\
\hline 8 & Kab. Banyuwangi & 51,12 & 0,00 & 15,61 & 33,27 \\
\hline
\end{tabular}


Komposisi pembiayaan operasional sekolah di SMA dan SMK tahun 2014/2015 pada berbagai kabupaten/kota serupa dengan komposisi pembiayaan tahun 2013/2014, yaitu sangat beragam, namun secara umum masih mengandalkan dana dari BOS dan iuran komite sekolah.

Proporsi pendanaan terbesar beragam antara kabupaten/kota yang satu dengan lainnya. Iuran komite sekolah memiliki proporsi pembiayaan terbesar juga pada separuh kabupaten/kota yang menjadi sampel, bahkan pada tiga per empat dari kabupaten/kota (Kabupaten Bogor, Kota Manado, dan Kota Salatiga) tersebut iuran komite sekolah memiliki kontribusi lebih dari 50 persen, bahkan Kota Manado mencapai 71,49 persen, dari seluruh pembiayaan operasional sekolah pada tahun 2014/2015.

Selanjutnya, sebagaimana halnya dengan tahun 2013/2014, BOS pusat mendominasi pembiayaan operasional sekolah pada tiga per delapan kabupaten/ kota, dengan satu kabupaten/kota (Kabupaten Jayapura) di antaranya memiliki kontribusi lebih dari 50 persen terhadap seluruh pembiayaan operasional sekolah pada tahun 2014/2015. Kontribusi sumber pembiayaan operasional ini berkisar dari 22,66 persen di Kabupaten Bogor sampai 51,74 persen di Kabupaten Jayapura dari seluruh pembiayaan operasional sekolah.

BOSDa kabupaten/kota memiliki kontribusi terbesar dalam pembiayaan operasional sekolah hanya pada satu dari delapan kabupaten/kota (Kabupaten Deli Serdang). Kontribusi tersebut besarnya adalah 38,18 persen dari seluruh nilai pembiayaan operasional sekolah.

BOSDa provinsi pada tahun 2014/2015 ini memiliki kontribusi terbesar pada pembiayaan operasional sekolah pada satu dari delapan kabupaten/kota sampel (Kota Samarinda). Kontribusi tersebut besarnya adalah 38,61 persen dari seluruh nilai pembiayaan operasional sekolah.

Fenomena yang mengejutkan, yaitu adanya kabupaten/kota dan provinsi yang tidak memiliki kontribusi secara rutin sama sekali terhadap pembiayaan operasional sekolah menengah di daerahnya juga ditemukan pada tahun 2014/2015. Pemda di tiga per delapan kabupaten/kota (Kabupaten Bogor, Kota Manado, dan Kota Salatiga) dari seluruh kabupaten/ kota sama sekali tidak memiliki kontribusi dalam pembiayaan operasional sekolah menengah di daerahnya. Demikian juga pemda di tiga per delapan (Kabupaten Deli Serdang, Kota Salatiga, dan Kabupaten Banyuwangi) dari seluruh provinsi tidak memiliki kontribusi secara rutin dalam pendidikan di daerahnya. Selain itu, terdapat seperempat dari seluruh sampel (Kabupaten Jayapura dan Kota Manado), provinsi hanya memiliki kontribusi minimal, yaitu 0,24 persen dan 0,99 persen dari seluruh pembiayaan operasional sekolah. 
Tabel 2.

Sumber Biaya Operasional Sekolah Tahun Ajaran 2014/2015 (dalam persen)

\begin{tabular}{|c|c|c|c|c|c|}
\hline No & $\begin{array}{l}\text { Kabupaten/ } \\
\text { Kota }\end{array}$ & $\begin{array}{l}\text { BOS } \\
\text { Pusat }\end{array}$ & $\begin{array}{c}\text { BOS } \\
\text { Provinsi }\end{array}$ & $\begin{array}{c}\text { BOS } \\
\text { Kabupaten/Kota }\end{array}$ & Iuran Komite \\
\hline 1 & Kab. Bogor & 22,66 & 6,99 & 0,00 & 70,34 \\
\hline 2 & Kab. Deli Serdang & 39,36 & 0,00 & 38,18 & 22,46 \\
\hline 3 & Kab. Gunung Kidul & 24,29 & 10,81 & 28,19 & 36,71 \\
\hline 4 & Kab. Jayapura & 51,74 & 0,24 & 15,34 & 32,68 \\
\hline 5 & Kota Manado & 27,52 & 0,99 & 0,00 & 71,49 \\
\hline 6 & Kota Salatiga & 36,71 & 0,00 & 0,00 & 63,29 \\
\hline 7 & Kota Samarinda & 32,09 & 38,61 & 21,01 & 8,29 \\
\hline 8 & Kab. Banyuwangi & 53,98 & 0,00 & 12,52 & 33,50 \\
\hline
\end{tabular}

Kontribusi pemerintah daerah kabupaten/ kota terhadap pembiayaan operasional sekolah menengah di daerah-daerah tidak selalu berkaitan dengan tinggi-rendahnya IKF di daerah itu. Daerah dengan IKF rendah tidak selalu berkontribusi rendah pula terhadap pembiayaan operasional sekolah. Terdapat dua kabupaten yang IKFnya tergolong rendah tetapi kontribusi dalam pendanaan operasional sekolah menengah tergolong tinggi, yaitu Kabupaten Gunung Kidul dan Deli Serdang. Dari sisi IKF Kabupaten Gunung Kidul tergolong rendah tetapi kontribusi dalam pendanaan biaya operasional sekolah pendidikan menengah tergolong tinggi mencapai 26,26 persen tahun 2013/2014 dan sebesar 28,19 persen pada tahun 2014/2015. Demikian pula Kabupaten Deli Sedang tergolong pada IKF rendah namun kontribusi pada pendidikan menengah cukup baik yakni mencapai 34,13 persen pada tahun 2013/2014 dan sebesar 38,18 persen pada tahun $2014 / 2015$.

Di sisi lain terdapat pula kabupaten/kota yang tergolong dengan IKF sedang kontribusi pendanaan pada pendidikan menengah tergolong rendah, yaitu Kota Salatiga dan Kota Manado (sama sekali tidak memberikan kontribusi pendanaan). Dengan demikian, besarnya kontribusi pendanaan pendidikan menengah dari kabupaten/kota tidak sematamata dipengaruhi oleh besarnya APBD, tetapi lebih kepada komitmen kepala daerah terhadap pendidikan.

\section{Pemanfaatan Sumber Dana di SMA dan SMK Tahun 2013/2014 dan 2014/2015 Sekolah Menengah Atas Negeri (SMAN)}

Pemanfaatan dana dari tiga sumber pembiayaan di SMAN mengacu pada petunjuk teknis dan sesuai dengan peruntukkannya masing-masing. Analisis ini dimulai dengan kecenderungan umum penggunaan dana dan selanjutnya disusul oleh analisis penggunaan dana untuk masing-masing sumber dana.

Terdapat dua kecenderungan menarik dalam penggunaan dana operasional SMA negeri ini. Kecenderungan pertama adalah bahwa dana dari sumber mana pun juga ternyata digunakan untuk membiayai semua komponen pembiayaan. Pengecualiannya hanyalah pada BOS dan BOSDa provinsi yang tidak digunakan untuk membiayai asuransi keamanan dan keselamatan sekolah. Kecenderungan kedua, di luar dana BOS 
terdapat proporsi yang besar dari masingmasing dana tersebut yang dibelanjakan untuk biaya operasional lainnya, misalnya untuk honorarium guru. Bahkan, untuk dana operasional sekolah yang berasal dari orang tua ternyata lebih dari 58 persennya digunakan untuk pos pengeluaran ini.

Dana BOSDa provinsi sebagian besar digunakan untuk biaya operasional sekolah lainnya yang kebanyakan digunakan sebagai honor guru baik untuk tahun 2013/2014 sebesar 41,90 persen maupun pada tahun
2014/2015 sebesar 36,34 persen. Selain itu, dana BOSDa provinsi juga digunakan untuk penyelenggaraan evaluasi pembelajaran, yaitu sebesar 13,33 persen (2014) dan 21,93 persen (2015), serta untuk pemeliharaan/ perbaikan sarana dan prasarana sekolah tahun 13,79 persen (2014) dan 8,17 persen (2015). Besarnya proporsi BOS provinsi untuk komponen biaya operasional lainnya khususnya gaji guru mengingat jumlah guru honorer yang banyak dan dana BOS tidak dapat digunakan untuk honor guru.

Tabel 3

\section{Penggunaan Dana di SMA Negeri}

\begin{tabular}{|c|c|c|c|c|c|c|c|c|c|}
\hline \multirow{2}{*}{ No } & \multirow{2}{*}{ Komponen Pengeluaran } & \multicolumn{2}{|c|}{$\begin{array}{l}\text { BOS } \\
(\%)\end{array}$} & \multicolumn{2}{|c|}{$\begin{array}{c}\text { BOS Provinsi } \\
(\%)\end{array}$} & \multicolumn{2}{|c|}{$\begin{array}{l}\text { BOS Kab/ } \\
\operatorname{kota}(\%)\end{array}$} & \multicolumn{2}{|c|}{ SPP/Komite (\%) } \\
\hline & & $\begin{array}{c}\text { Jan - } \\
\text { Des } 14\end{array}$ & $\begin{array}{c}\text { Jan - Jun } \\
15\end{array}$ & $\begin{array}{c}\text { Jan - } \\
\text { Des } 14\end{array}$ & $\begin{array}{l}\text { Jan - } \\
\text { Juli } 15\end{array}$ & $\begin{array}{c}\text { Jan - } \\
\text { Des } 14\end{array}$ & $\begin{array}{l}\text { Jan - } \\
\text { Juli } 15\end{array}$ & $\begin{array}{c}\text { Jan - } \\
\text { Des } 14\end{array}$ & $\begin{array}{l}\text { Jan - } \\
\text { Juli } 15\end{array}$ \\
\hline 1 & Pengadaan Buku Kurikulum 2013 & 20,40 & 1,73 & 0,61 & - & 0,67 & - & - & - \\
\hline 2 & Pengadaan Buku Teks Pelajaran & 21,86 & 5,01 & 0,64 & 0,93 & 0,18 & 0,12 & 0,13 & 0,15 \\
\hline 3 & Pengadaan Alat Tulis Sekolah & 4,84 & 9,49 & 4,21 & 4,10 & 9,80 & 13,10 & 1,16 & 0,31 \\
\hline 4 & $\begin{array}{l}\text { Penyelenggaraan Evaluasi } \\
\text { Pembelajaran }\end{array}$ & 5,98 & 13,97 & 13,33 & 21,93 & 8,62 & 4,54 & 4,41 & 4,00 \\
\hline 5 & Pengadaan Alat Habis Pakai & 3,52 & 7,92 & 3,97 & 7,67 & 5,48 & 6,16 & 1,23 & 0,82 \\
\hline 6 & Pengadaan Bahan Habis Pakai & 15,24 & 4,02 & 5,45 & 6,02 & 15,21 & 21,17 & 1,55 & 8,25 \\
\hline 7 & $\begin{array}{l}\text { Kegiatan Pembinaan Siswa/ } \\
\text { Ekstrakurikuler }\end{array}$ & 9,55 & 23,98 & 8,28 & 8,30 & 5,47 & 0,36 & 12,09 & 2,65 \\
\hline 8 & $\begin{array}{l}\text { Pemeliharaan dan Perbaikan Rusak } \\
\text { Ringan Sarana/Prasarana Sekolah }\end{array}$ & 8,29 & 17,17 & 13,79 & 8,17 & 22,60 & 24,91 & 5,04 & 6,38 \\
\hline 9 & Langganan Daya dan Jasa Lainnya & 3,68 & 6,99 & 2,05 & 0,85 & 9,57 & 7,88 & 5,39 & 8,89 \\
\hline 10 & Kegiatan Penerimaan Siswa Baru & 2,17 & 2,79 & 2,51 & 1,29 & 1,29 & 0,04 & 2,84 & 2,06 \\
\hline 11 & $\begin{array}{l}\text { Website sekolah, CCTV, Software } \\
\text { Pembelajaran }\end{array}$ & 3,62 & 1,71 & 0,40 & 0,37 & 0,28 & 0,04 & 0,58 & 0,49 \\
\hline 12 & $\begin{array}{l}\text { Entry data individual sekolah } \\
\text { melalui aplikasi Dapodik }\end{array}$ & 0,47 & 0,81 & - & 0,13 & 0,18 & 0,04 & 0,02 & 0,05 \\
\hline 13 & $\begin{array}{l}\text { Pengembangan profesi guru dan } \\
\text { tenaga kependidikan }\end{array}$ & 0,10 & 3,69 & 2,59 & 0,83 & 1,34 & 0,13 & 6,34 & 7,14 \\
\hline 14 & $\begin{array}{l}\text { Biaya asuransi keamanan dan } \\
\text { keselamatan sekolah }\end{array}$ & - & 0,31 & - & - & 1,76 & 0,04 & 0,15 & 0,25 \\
\hline 15 & Penyusunan dan Pelaporan & 0,29 & 0,42 & 0,28 & 3,06 & 0,09 & 0,98 & 0,29 & 0,09 \\
\hline 16 & $\begin{array}{l}\text { Biaya Operasional Lainnya, contoh } \\
\text { untuk honor guru }\end{array}$ & - & - & 41,90 & 36,34 & 17,45 & $\mathbf{2 0 , 5 0}$ & 58,77 & 58,47 \\
\hline
\end{tabular}


BOSDa kabupaten/kota terbesar digunakan untuk pemeliharaan sarana dan prasarana, yaitu pada tahun 2014 sebesar 22,60 persen dan tahun 2015 sebesar 24,91 persen. Persentase pada komponen lain yang tidak jauh berbeda digunakan untuk operasional lainnya terutama untuk honor guru pada tahun 2014 sebesar 17,45 persen dan 2015 sebesar 20,50 persen dan komponen pengadaan bahan habis pakai pada tahun 2014 sebesar 15,21 persen dan 2015 sebesar 21,17 persen. Pembiayaan lainnya yang cukup besar digunakan untuk pengadaan alat tulis sekolah pada tahun 2014 sebesar 9,80 persen dan 2015 sebesar 13,10 persen.

Iuran komite atau sumbangan pembinaan pendidikan (SPP) sebagian besar digunakan untuk komponen biaya operasional lainnya tahun 2014 sebesar 58,77 persen dan tahun 2015 sebesar 58,47 persen. Selain itu, persentase biaya cukup besar dari iuran komite ini juga digunakan untuk penyelenggaraan kegiatan kesiswaan/ekstrakurikuler pada tahun 2014 sebesar 12,09 persen dan langganan daya dan jasa sebesar 8,89 persen pada tahun 2015.

Komponen pembiayaan untuk penyelenggaraan evaluasi pembelajaran menggunakan dana dari BOS pusat dan BOS provinsi, pemeliharaan sarana dan prasarana menggunakan dana dari BOS Pusat, BOS Provinsi, dan BOS Kabupaten/kota, dan komponen biaya operasional lainnya menggunakan sumber dana dari BOS Provinsi, BOS Kabupaten/kota, dan iuran komite. Hal ini mengindikasikan bahwa komponen-komponen tersebut memerlukan biaya yang cukup besar jika dibandingkan dengan komponen-komponen operasional sekolah lainnya.
Bantuan pendanaan operasional sekolah dari pemerintah daerah relatif kecil dan proporsinya menurun dari tahun 2013/2014 ke tahun 2014/2015 seiring dengan naiknya besaran dana BOS dari pemerintah pusat. Bantuan pendanaan operasional sekolah dari pemerintah provinsi sebesar 9,56 persen pada tahun 2013/2014 berkurang menjadi 7,10 persen. Bantuan pendanaan operasional sekolah dari pemerintah kabupaten/kota sebesar 13,41 persen pada tahun 2013/2014 berkurang menjadi 11,33 persen pada tahun 2014/2015 (grafik 1 dan 2).

Besarnya bantuan dana pendidikan dari pemerintah daerah untuk pendidikan menengah, tersebut ternyata tidak terkait dengan tinggi dan pendapatan asli daerah (PAD) kabupaten/kota. Besarnya bantuan ini lebih dipengaruhi oleh komitmen pimpinan pemerintahan daerah terhadap pendidikan.

\section{Sekolah Menengah Atas Swasta (SMAS)}

Perbedaan penggunaan dana operasional sekolah negeri dan sekolah swasta terletak pada komposisi dan komponen yang dibiayai. Pada sekolah negeri, komponen pengadaan buku kurikulum 2013, penyelenggaraan evaluasi pembelajaran, dan pengadaan alat/ bahan habis pakai menggunakan persentase yang cukup besar dari sumber dana operasional sekolah. Pada sekolah swasta persentase yang sangat mencolok dari sumber dana digunakan untuk membiayai operasional lainnya seperti honor guru dan yang lainnya.

Secara umum juga terdapat dua kecenderungan menarik dalam penggunaan dana operasional SMA swasta ini. Kecenderungan pertama adalah bahwa pola penggunaan dana operasional dari BOS pusat dan Komite Sekolah digunakan untuk 
membiayai semua pos pengeluaran, kecuali pada periode Januari s.d. Juni 2015 dana dari kedua sumber ini tidak digunakan untuk membiayai pengadaan buku Kurikulum 2013. Sementara itu, dana dari BOSDa provinsi dan BOSDa kabupaten/kota cenderung terfokus pada pos-pos tertentu terutama untuk honor guru. Sebagai contoh, dana dari BOSDa provinsi dan BOSDa kabupaten/kota tidak pernah digunakan untuk membiayai website sekolah, CCTV, dan software pembelajaran. Selain itu, pada periode Januari s.d Juni 2015 dana dari kedua sumber tersebut juga tidak digunakan untuk penyelenggaraan kegiatan pembinaan siswa/ekstrakurikuler, pengadaan buku Kurikulum 2013, pengembangan profesi guru dan tenaga kependidikan, serta langganan daya dan jasa lainnya. Selanjutnya, jauh lebih terfokusnya penggunaan dana SMA swasta ditunjukkan pada pola penggunaan dana BOSDa kabupaten/kota pada periode Januari s.d. Juni 2015. Pada periode ini dana tersebut hanya digunakan untuk membiayai empat pos pengeluaran, yang salah satu di antaranya adalah biaya operasional lainnya termasuk untuk honorarium guru. Pos pengeluaran biaya operasional lainnya temasuk untuk honorarium guru ini sampai menghabiskan 96,56 persen dari dana operasional BOSDa kabupaten/kota pada periode Januari s.d. Juni 2015.

Tabel 4

\section{Penggunaan Dana di SMA Swasta}

\begin{tabular}{|c|c|c|c|c|c|c|c|c|c|}
\hline \multirow{2}{*}{ No } & \multirow{2}{*}{ Komponen Pengeluaran } & \multicolumn{2}{|c|}{ BOS $(\%)$} & \multicolumn{2}{|c|}{$\begin{array}{c}\text { BOS Provinsi } \\
(\%)\end{array}$} & \multicolumn{2}{|c|}{$\begin{array}{l}\text { BOS Kabupaten/ } \\
\text { kota }(\%)\end{array}$} & \multicolumn{2}{|c|}{ SPP/Komite (\%) } \\
\hline & & $\begin{array}{l}\text { Jan - } \\
\text { Des } 14\end{array}$ & $\begin{array}{c}\text { Jan - } \\
\text { Juni } 15\end{array}$ & $\begin{array}{c}\text { Jan - } \\
\text { Des } 14\end{array}$ & $\begin{array}{l}\text { Jan - } \\
\text { Juni } 15\end{array}$ & $\begin{array}{c}\text { Jan - } \\
\text { Des } 14\end{array}$ & $\begin{array}{c}\text { Jan - } \\
\text { Juni } 15\end{array}$ & $\begin{array}{l}\text { Jan - } \\
\text { Des } 14\end{array}$ & $\begin{array}{l}\text { Jan - } \\
\text { Jun } 15\end{array}$ \\
\hline 1 & Pengadaan Buku Kurikulum 2013 & 12,76 & 0,00 & 1,33 & - & 0,50 & - & 0,43 & - \\
\hline 2 & Pengadaan Buku Teks Pelajaran & 14,19 & 16,86 & 0,59 & 1,03 & 2,75 & - & 0,73 & 1,11 \\
\hline 3 & Pengadaan Alat Tulis Sekolah & 5,99 & 6,94 & 0,86 & 0,81 & 5,67 & 1,05 & 0,88 & 1,09 \\
\hline 4 & $\begin{array}{l}\text { Penyelenggaran Evaluasi } \\
\text { Pembelajaran }\end{array}$ & 8,25 & 9,22 & 2,83 & 0,69 & 1,85 & - & 1,53 & 2,90 \\
\hline 5 & Pengadaan Alat Habis Pakai & 6,65 & 9,23 & 1,66 & 0,17 & 3,07 & 1,67 & 0,78 & 0,91 \\
\hline 6 & Pengadaan Bahan Habis Pakai & 4,75 & 6,16 & 2,92 & 0,23 & 5,05 & - & 1,12 & 0,66 \\
\hline 7 & $\begin{array}{l}\text { Penyelenggaraan Kegiatan } \\
\text { Pembinaan Siswa/Ekstrakurikuler }\end{array}$ & 17,09 & 20,73 & 8,46 & & 7,19 & - & 2,19 & 10,07 \\
\hline 8 & $\begin{array}{l}\text { Pemeliharaan dan Perbaikan } \\
\text { Rusak Ringan Sarpras Sekolah }\end{array}$ & 11,93 & 12,39 & 10,04 & 0,45 & 4,72 & & 2,62 & 2,02 \\
\hline 9 & Langganan Daya dan Jasa Lainnya & 9,75 & 11,70 & 1,42 & - & 1,24 & - & 0,20 & 1,00 \\
\hline 10 & Kegiatan Penerimaan Siswa Baru & 2,09 & 2,97 & 1,86 & 0,86 & 0,50 & 0,72 & 0,33 & 0,38 \\
\hline 11 & $\begin{array}{l}\text { Website sekolah, CCTV, Software } \\
\text { Pembelajaran }\end{array}$ & 1,56 & 0,85 & - & & - & - & 0,39 & 0,35 \\
\hline 12 & $\begin{array}{l}\text { Entry data individual sekolah } \\
\text { melalui aplikasi Dapodik }\end{array}$ & 0,61 & 1,03 & 0,04 & 0,22 & 0,55 & & 0,11 & 0,02 \\
\hline 13 & $\begin{array}{l}\text { Pengembangan profesi guru dan } \\
\text { tenaga kependidikan }\end{array}$ & 3,08 & 1,18 & 7,27 & & 2,66 & & 0,39 & 0,33 \\
\hline 14 & $\begin{array}{l}\text { Biaya asuransi keamanan dan } \\
\text { keselamatan sekolah }\end{array}$ & 0,61 & 0,00 & 0,05 & 0,07 & 1,99 & & 0,06 & 0,30 \\
\hline 15 & Penyusunan dan Pelaporan & 0,70 & 0,75 & 0,42 & 0,09 & 0,27 & - & 0,00 & 2,10 \\
\hline 16 & $\begin{array}{l}\text { Biaya Operasional Lainnya, } \\
\text { contoh untuk honor guru }\end{array}$ & & & 60,24 & 95,37 & 61,98 & 96,56 & 88,22 & 76,77 \\
\hline
\end{tabular}


Kecenderungan kedua, di luar dana BOS ternyata proporsi yang sangat besar dari masing-masing dana tersebut yang dibelanjakan untuk biaya operasional lainnya, misalnya untuk honorarium guru. Antara 60,24 persen sampai 96,56 persen dana dari masing-masing BOSDa provinsi, BOSDa kabupaten/kota dan Komite Sekolah digunakan untuk pos pengeluaran ini.

Bantuan operasional sekolah yang bersumber dari pemerintah daerah baik itu tingkat provinsi ataupun tingkat kabupaten/ kota sebagian besar digunakan untuk membiayai operasional sekolah seperti honor guru dan lain-lain. Komponen tersebut membiayai sebanyak 60,24 persen pada tahun 2014 dan 95,37 persen pada tahun 2015.

Bantuan dana operasional yang diberikan oleh pemerintah kabupaten/kota (BOSDa kabupaten/kota) pada tahun 2014 dan pada tahun 2015 sama halnya dengan BOSDa provinsi, persentase terbesar BOSDa kabupaten/kota juga digunakan untuk membiayai komponen biaya operasional sekolah lainnya seperti honor guru, yaitu 61,98 persen pada tahun 2014 dan 96,56 persen pada tahun 2015. Perbedaan penggunaan bantuan dana terlihat pada tahun 2014 di mana bantuan dana yang bersumber dari BOS provinsi sebanyak 10,04 persen digunakan untuk membiayai pemeliharaan sarana dan prasarana sedangkan untuk kabupaten/kota sebesar 4,72 persen.

Sumber dana terakhir untuk membiayai sekolah adalah iuran komite atau SPP yang dibayarkan siswa setiap bulannya. Iuran komite ini digunakan sebagian besarnya untuk pembiayaan operasional lainnya seperti honor guru baik pada tahun 2014 (88,22 persen) dan tahun $2015 \quad(76,77$ persen). Pada tahun 2015, iuran komite juga digunakan untuk membiayai komponen penyelenggaraan kegiatan pembinaan siswa sebesar 10,07 persen.

\section{Sekolah Menengah Kejuruan Negeri (SMKN)}

Pemanfaatan dana di SMKN juga terdapat dua kecenderungan menarik dalam penggunaan dana operasional. Kecenderungan pertama adalah bahwa pola penggunaan dana operasional dari BOS pusat dan Komite Sekolah digunakan untuk membiayai semua pos pengeluaran, kecuali dana dari Komite Sekolah tidak digunakan untuk membiayai pengadaan buku Kurikulum 2013. Sementara itu, dana dari BOSDa provinsi dan BOSDa kabupaten/ kota, walaupun tidak nampak terpola pada pos-pos tertentu, namun cenderung dialokasikan pada pos-pos pengeluaran yang lebih sedikit jenisnya. Sebagai contoh, dana dari BOSDa kabupaten/kota tidak pernah digunakan untuk membiayai asuransi keamanan dan keselamatan sekolah. Selain itu, pada periode Januari s.d. Desember 2014 dana dari BOSDa provinsi tidak digunakan untuk entry data individual sekolah melalui aplikasi Dapodik dan asuransi keamanan dan keselamatan sekolah. Namun, pada periode Januari s.d. Juni 2015 dana BOSDa provinsi digunakan juga untuk membiayai kedua pos pengeluaran tersebut.

Kecenderungan kedua, di luar dana BOS (pusat) ternyata proporsi yang besar dari masing-masing dana tersebut yang dibelanjakan untuk biaya operasional lainnya, misalnya untuk honorarium guru. Antara 45,17 persen sampai 64,01 persen dana dari masing-masing BOSDa provinsi, 
BOSDa kabupaten/kota dan Komite Sekolah digunakan untuk pos pengeluaran ini. Perlu ditambahkan bahwa proporsi terbesar penggunaan untuk pos ini adalah dana dari Komite Sekolah. Antara 63,28 persen s.d. 64,01 persen dari dana yang berasal dari komite ini digunakan untuk membiayai pos tersebut.

Bantuan operasional sekolah yang berasal dari pemerintah provinsi (BOSDa provinsi) membantu biaya operasional lainnya seperti honor guru sebesar 52,94 persen tahun 2014 dan tahun 2015 sebesar 45,17 persen. Penggunaan dana pada komponen ini merupakan persentase terbesar jika dibandingkan dengan komponen pembiayaan lainnya. Bantuan dana operasional sekolah yang berasal dari BOSDa kabupaten/kota tahun 2014 dan tahun 2015 penggunaannya umumnya sama dengan sumber dana BOS provinsi, yaitu sebagian besar digunakan untuk membiayai biaya operasional sekolah personalia. Dana BOSDa kabupaten/kota pada tahun 2014 pada komponen operasional lainnya sebesar 41,97 persen dan tahun 2015 sebesar 48,21 persen.

Tabel 5

Penggunaan Dana di SMK Negeri

\begin{tabular}{|c|c|c|c|c|c|c|c|c|c|}
\hline \multirow{2}{*}{ No. } & \multirow{2}{*}{ Komponen Pengeluaran } & \multicolumn{2}{|c|}{$\begin{array}{l}\text { BOS } \\
(\%)\end{array}$} & \multicolumn{2}{|c|}{$\begin{array}{l}\text { BOS Provinsi } \\
(\%)\end{array}$} & \multicolumn{2}{|c|}{$\begin{array}{l}\text { BOS Kabupaten/ } \\
\text { kota }(\%)\end{array}$} & \multicolumn{2}{|c|}{$\begin{array}{c}\text { SPP/Komite } \\
(\%)\end{array}$} \\
\hline & & $\begin{array}{l}\text { Jan - } \\
\text { Des } 14\end{array}$ & $\begin{array}{c}\text { Jan - } \\
\text { Juni } 15\end{array}$ & $\begin{array}{c}\text { Jan - } \\
\text { Des } 14\end{array}$ & $\begin{array}{c}\text { Jan - } \\
\text { Juni } 15\end{array}$ & $\begin{array}{c}\text { Jan - } \\
\text { Des } 14\end{array}$ & $\begin{array}{c}\text { Jan - } \\
\text { Juni } 15\end{array}$ & $\begin{array}{c}\text { Jan - } \\
\text { Des } 14\end{array}$ & $\begin{array}{c}\text { Jan - } \\
\text { Juni } 15\end{array}$ \\
\hline 1 & Pengadaan Buku Kurikulum 2013 & 5,52 & 2,65 & 1,22 & 0,97 & 0,03 & - & 0,00 & - \\
\hline 2 & Pengadaan Buku Teks Pelajaran & 3,55 & 4,40 & 0,77 & 0,38 & 0,44 & 0,04 & 0,13 & 0,21 \\
\hline 3 & Pengadaan Alat Tulis Sekolah & 7,54 & 5,77 & 5,81 & 6,12 & 6,85 & 4,57 & 0,92 & 0,34 \\
\hline 4 & $\begin{array}{l}\text { Penyelenggaraan Evaluasi } \\
\text { Pembelajaran }\end{array}$ & 8,77 & 10,30 & 3,26 & 1,46 & 4,08 & 2,56 & 15,09 & 12,84 \\
\hline 5 & Pengadaan Alat Habis Pakai & 13,86 & 9,54 & 2,92 & 7,22 & 6,54 & 7,48 & 1,10 & 3,26 \\
\hline 6 & Pengadaan Bahan Habis Pakai & 21,48 & 28,04 & 8,25 & 7,22 & 15,21 & 9,33 & 3,01 & 1,58 \\
\hline 7 & $\begin{array}{l}\text { Penyelenggaraan Kegiatan } \\
\text { Pembinaan Siswa/Ekstrakurikuler }\end{array}$ & 3,77 & 5,22 & 8,17 & 5,05 & 0,86 & 0,92 & 3,09 & 5,02 \\
\hline 8 & $\begin{array}{l}\text { Pemeliharaan dan Perbaikan } \\
\text { Rusak Ringan Sarana/Prasarana } \\
\text { Sekolah }\end{array}$ & 16,46 & 13,06 & 4,32 & 9,84 & 13,17 & 14,60 & 7,09 & 3,11 \\
\hline 9 & $\begin{array}{l}\text { Langganan Daya dan Jasa } \\
\text { Lainnya }\end{array}$ & 4,99 & 6,23 & 5,15 & 6,05 & 8,42 & 10,48 & 2,19 & 1,00 \\
\hline 10 & Kegiatan Penerimaan Siswa Baru & 2,15 & 2,06 & 1,35 & 1,43 & 0,47 & 0,16 & 0,47 & 0,53 \\
\hline 11 & $\begin{array}{l}\text { Website sekolah, CCTV, Software } \\
\text { Pembelajaran }\end{array}$ & 9,08 & 4,10 & 5,22 & 6,34 & 0,76 & 1,04 & 0,00 & 0,39 \\
\hline 12 & $\begin{array}{l}\text { Entry data individual sekolah } \\
\text { melalui aplikasi Dapodik }\end{array}$ & 0,74 & 2,83 & - & 0,24 & 0,02 & - & 0,13 & \\
\hline 13 & $\begin{array}{l}\text { Pengembangan profesi guru dan } \\
\text { tenaga kependidikan }\end{array}$ & 0,65 & 2,15 & 0,31 & 0,35 & 0,82 & 0,50 & 1,49 & 3,20 \\
\hline 14 & $\begin{array}{l}\text { Biaya asuransi keamanan dan } \\
\text { keselamatan sekolah }\end{array}$ & 0,40 & 5,33 & - & 1,59 & - & - & 1,85 & 4,35 \\
\hline 15 & Penyusunan dan Pelaporan & 1,05 & 0,54 & 0,30 & 0,57 & 0,36 & 0,10 & 0,15 & 0,17 \\
\hline 16 & $\begin{array}{l}\text { Biaya Operasional Lainnya, } \\
\text { contoh untuk honor guru }\end{array}$ & - & - & 52,94 & 45,17 & 41,97 & 48,21 & 63,28 & 64,01 \\
\hline
\end{tabular}


Secara umum penggunaan dana dari berbagai sumber dana baik dari pemerintah pusat, pemerintah provinsi, kabupaten/ kota, dan dari iuran komite digunakan untuk operasional sekolah. Namun, terdapat perbedaan penggunaan antara dana BOSDa provinsi dengan BOSDa kabupaten/kota dan iuran komite. Ada beberapa komponen yang persentase penggunaan dana BOSDa kabupaten/kota cukup besar seperti pengadaan bahan habis pakai pada tahun 2014 sebesar 15,21 persen, dan pemeliharaan sarana prasarana 13,17 persen. Pemanfaatan dana pada komponen ini tergolong cukup besar karena untuk perbaikan prasarana sekolah seperti perbaikan ruangan. Pada tahun 2015 penggunaan data pada komponen ini cenderung naik menjadi 14,60 persen. Persentase penggunaan dana iuran komite yang cukup besar juga terdapat pada penyelenggaraan evaluasi belajar tahun 2014 sebesar 15,09 persen dan tahun 2015 sebesar 12,84 persen.

\section{Sekolah Menengah Kejuruan Swasta (SMKS)}

Pemanfaatan dana di SMK swasta juga terdapat dua kecenderungan menarik dalam penggunaan dana operasional. Kecenderungan pertama adalah bahwa dana operasional dari BOS pusat dan Komite Sekolah digunakan untuk membiayai semua pos pengeluaran, kecuali dana dari Komite Sekolah periode Januari s.d. Juni 2015 tidak digunakan untuk membiayai pengadaan buku Kurikulum 2013. Sementara itu, dana dari BOSDa provinsi dan BOSDa kabupaten/kota cenderung terpola pada pos-pos tertentu. Untuk SMK swasta, penggunaan dana cenderung lebih terfokus lagi jika dibandingkan dengan SMA swasta. Sebagai contoh, dana dari BOSDa provinsi dan BOSDa kabupaten/ kota tidak pernah digunakan untuk membiayai website sekolah, CCTV, dan software pembelajaran.

Tabel 6

Penggunaan Dana di SMK Swasta

\begin{tabular}{|c|c|c|c|c|c|c|c|c|c|}
\hline \multirow{2}{*}{ No } & \multirow{2}{*}{ Komponen Pengeluaran } & \multicolumn{2}{|c|}{$\begin{array}{l}\text { BOS } \\
(\%)\end{array}$} & \multicolumn{2}{|c|}{$\begin{array}{c}\text { BOS Provinsi } \\
(\%)\end{array}$} & \multicolumn{2}{|c|}{$\begin{array}{c}\text { BOS Kabupaten/ } \\
\text { kota }(\%)\end{array}$} & \multicolumn{2}{|c|}{$\begin{array}{c}\text { SPP/Komite } \\
(\%)\end{array}$} \\
\hline & & $\begin{array}{l}\text { Jan - } \\
\text { Des } 14\end{array}$ & $\begin{array}{c}\text { Jan - } \\
\text { Juni } 15\end{array}$ & $\begin{array}{c}\text { Jan - } \\
\text { Des } 14\end{array}$ & $\begin{array}{c}\text { Jan - } \\
\text { Juni } 15\end{array}$ & $\begin{array}{l}\text { Jan - } \\
\text { Des } 14\end{array}$ & $\begin{array}{c}\text { Jan - } \\
\text { Jun } 15 \\
\end{array}$ & $\begin{array}{c}\text { Jan - } \\
\text { Des } 14\end{array}$ & $\begin{array}{c}\text { Jan - } \\
\text { Jun } 15\end{array}$ \\
\hline 1 & Pengadaan Buku Kurikulum 2013 & 4,07 & 2,83 & 0,15 & - & 0,46 & - & 0,10 & - \\
\hline 2 & Pengadaan Buku Teks Pelajaran & 3,72 & 6,45 & 0,25 & 2,81 & 0,62 & - & 0,36 & 1,24 \\
\hline 3 & Pengadaan Alat Tulis Sekolah & 6,58 & 6,80 & 0,18 & 2,67 & 3,80 & - & 0,65 & 0,88 \\
\hline 4 & $\begin{array}{l}\text { Penyelenggaraan Evaluasi } \\
\text { Pembelajaran }\end{array}$ & 8,08 & 10,56 & 7,88 & 7,73 & 3,57 & 9,09 & 3,51 & 3,22 \\
\hline 5 & Pengadaan Alat Habis Pakai & 25,04 & 13,29 & 0,39 & - & 0,38 & - & 1,57 & 0,30 \\
\hline 6 & Pengadaan Bahan Habis Pakai & 16,76 & 17,52 & 2,04 & 3,13 & 6,09 & - & 0,97 & 1,10 \\
\hline 7 & $\begin{array}{l}\text { Penyelenggaraan Kegiatan } \\
\text { Pembinaan Siswa/Ekstrakurikuler }\end{array}$ & 4,56 & 4,65 & 2,38 & 2,32 & 16,71 & - & 0,52 & 0,35 \\
\hline 8 & $\begin{array}{l}\text { Pemeliharaan dan Perbaikan Rusak } \\
\text { Ringan Sarana/Prasarana Sekolah }\end{array}$ & 12,24 & 13,21 & 0,42 & 1,76 & 11,13 & - & 2,90 & 3,16 \\
\hline 9 & Langganan Daya dan Jasa Lainnya & 3,45 & 4,69 & 0,27 & 2,78 & 6,18 & - & 0,91 & 1,30 \\
\hline 10 & Kegiatan Penerimaan Siswa Baru & 2,32 & 3,55 & 0,65 & - & 0,73 & - & 0,76 & 1,27 \\
\hline
\end{tabular}




\begin{tabular}{|c|c|c|c|c|c|c|c|c|c|}
\hline \multirow{2}{*}{ No } & \multirow{2}{*}{ Komponen Pengeluaran } & \multicolumn{2}{|c|}{$\begin{array}{l}\text { BOS } \\
(\%)\end{array}$} & \multicolumn{2}{|c|}{$\begin{array}{l}\text { BOS Provinsi } \\
(\%)\end{array}$} & \multicolumn{2}{|c|}{$\begin{array}{l}\text { BOS Kabupaten/ } \\
\text { kota }(\%)\end{array}$} & \multicolumn{2}{|c|}{$\begin{array}{l}\text { SPP/Komite } \\
\quad(\%)\end{array}$} \\
\hline & & $\begin{array}{c}\text { Jan - } \\
\text { Des } 14\end{array}$ & $\begin{array}{c}\text { Jan - } \\
\text { Juni } 15\end{array}$ & $\begin{array}{c}\text { Jan - } \\
\text { Des } 14\end{array}$ & $\begin{array}{c}\text { Jan - } \\
\text { Juni } 15\end{array}$ & $\begin{array}{c}\text { Jan - } \\
\text { Des } 14\end{array}$ & $\begin{array}{l}\text { Jan - } \\
\text { Jun } 15\end{array}$ & $\begin{array}{l}\text { Jan - } \\
\text { Des } 14\end{array}$ & $\begin{array}{l}\text { Jan - } \\
\text { Jun } 15\end{array}$ \\
\hline 11 & $\begin{array}{l}\text { Website sekolah, CCTV, Software } \\
\text { Pembelajaran }\end{array}$ & 3,99 & 3,89 & - & - & - & & 0,06 & 0,13 \\
\hline 12 & $\begin{array}{l}\text { Entry data individual sekolah } \\
\text { melalui aplikasi Dapodik }\end{array}$ & 3,54 & 1,79 & - & - & 0,60 & 6,06 & 0,05 & 10,63 \\
\hline 13 & $\begin{array}{l}\text { Pengembangan profesi guru dan } \\
\text { tenaga kependidikan }\end{array}$ & 1,82 & 5,04 & 0,95 & - & 14,38 & - & 12,15 & 0,29 \\
\hline 14 & $\begin{array}{l}\text { Biaya asuransi keamanan dan } \\
\text { keselamatan sekolah }\end{array}$ & 0,90 & 5,28 & - & 0,21 & 14,18 & - & 0,51 & 0,25 \\
\hline 15 & Penyusunan dan Pelaporan & 0,69 & 0,46 & 0,11 & - & 1,88 & 8,48 & 0,01 & 0,00 \\
\hline 16 & $\begin{array}{l}\text { Biaya Operasional Lainnya, contoh } \\
\text { untuk honor guru }\end{array}$ & - & - & 84,33 & 76,60 & 19,31 & 76,36 & 74,96 & 75,88 \\
\hline
\end{tabular}

Selain itu, pada periode Januari s.d Juni 2015 dana dari kedua sumber tersebut juga tidak digunakan untuk pengadaan buku Kurikulum 2013, pengadaan alat habis pakai, penerimaan siswa baru, pengembangan profesi guru dan tenaga kependidikan. Jauh lebih terfokusnya penggunaan dana di SMK swasta ditunjukkan juga oleh kenyataan bahwa dana dari BOSDa kabupaten/kota pada periode Januari s.d. Juni 2015 hanya digunakan untuk membiayai empat pos pengeluaran, yaitu penyelenggaran evaluasi pembelajaran, entry data individual sekolah melalui aplikasi Dapodik, penyusunan dan pelaporan dan satu di antaranya yang terbesar adalah biaya operasional lainnya termasuk honorarium guru. Biaya operasional lainnya termasuk honorarium guru ini menghabiskan 76,36 persen dari BOSDa kabupaten/kota yang diterima di SMK swasta.

Kecenderungan kedua, di luar dana BOS (pusat) ternyata proporsi yang sangat besar dari masing-masing dana tersebut yang dibelanjakan untuk biaya operasional lainnya, misalnya untuk honorarium guru. Antara 74,96 persen sampai 84,33 persen dana dari masing-masing BOSDa provinsi,
BOSDa kabupaten/kota dan Komite Sekolah digunakan untuk pos pengeluaran ini pada periode Januari s.d. Desember 2014 dan Januari s.d. Juni 2015. Pengecualiannya adalah untuk dana BOSDa kabupaten/ kota periode Januari s.d. Desember 2014. Ketika itu penggunaan dana untuk pos ini hanya 19,31 persen. Namun, ini adalah pos pengeluaran terbesar untuk sumber dana ini pada periode tersebut.

Pada SMK swasta dana BOSDa dari pemerintah provinsi sebagian besar digunakan untuk biaya operasional lainnya. Dana yang bersumber dari pemerintah provinsi tersebut pada tahun 2014 dapat membantu memenuhi biaya operasional lainnya seperti untuk honor guru sebesar 84,33 persen dan tahun 2015 sebesar 76,60 persen.

Dana BOSDa dari kabupaten/kota untuk SMK swasta juga sebagian besar digunakan untuk komponen biaya operasional lainnya seperti untuk honor guru tahun 2014 sebesar 19,31 persen dan tahun 2015 sebesar 76,36 persen. Besarnya komponen biaya operasional lainnya pada sekolah swsta umumnya digunakan untuk honor guru, yang memerlukan biaya cukup besar. Selain itu, 
pada tahun 2014, komponen lainnya yang mendapatkan persentase dana yang cukup besar adalah penyelenggaraan kegiatan siswa sebesar 16,71 persen, pengembangan profesi guru sebesar 14,38 persen, dan biaya asuransi keamanan dan keselamatan sekolah sebesar 14,18 persen.

Pada SMK swasta iuran komite merupakan sumber utama dalam memenuhi biaya operasional sekolah. Pada tahun 2014 iuran komite pada SMKS digunakan untuk berbagai komponen, namun yang terbesar digunakan untuk kebutuhan operasional lainnya seperti untuk honor guru sebesar 74,96 persen. Iuran komite juga digunakan untuk pengembangan profesi guru dan tenaga kependidikan sebesar 12,15 persen, yang merupakan terbesar kedua dibandingkan dengan komponen lainnya. Tahun 2015 iuran komite terbesar juga digunakan untuk biaya operasional lainnya seperti untuk honor guru sebesar 75,88 persen, dan terbesar kedua sebesar 10,63 persen digunakan untuk honor entry data Dapodik pelaksanaan BOS tahun 2015.

\section{Meningkatkan Mutu Pembelajaran}

Salah satu tujuan BOS adalah dapat meningkatkan mutu pendidikan, salah satu upayanya melalui kegiatan pembelajaran. Dalam rangka meningkatkan mutu pembelajaran, peruntukan dana BOS memang difokuskan pada kegiatankegiatan operasional yang berkaitan dengan peningkatan mutu pembelajaran. Kegiatankegiatan operasional tersebut adalah pengadaan buku, pengadaan alat dan bahan habis pakai, pembiayaan langganan daya dan jasa, pemeliharaan dan perbaikan sarana dan prasarana rusak ringan, pembinaan siswa atau kegiatan ekstrakurikuler, serta pengembangan profesi guru dan tenaga kependidikan. Sebagai contoh penekanan pemanfaatan dana BOS pada komponenkomponen operasional yang berkaitan dengan peningkatan mutu pada tahun 2014, yaitu kurun waktu Januari s.d. Desember 2014, adalah pengadaan buku siswa yang meliputi buku Kurikulum 2013 dan buku teks lainnya dibiayai dengan dana sebesar 42,26 persen di SMA negeri dan 26,95 persen di SMA swasta serta 9,07 persen di SMK negeri dan 7,79 persen di SMK swasta. Selanjutnya, pengadaan alat dan bahan habis pakai, perbaikan sarana dan prasarana rusak ringan, serta langganan daya dan jasa secara keseluruhan dibiayai dengan dana sebesar 30,73 persen di SMA negeri dan 33,08 persen di SMA swasta serta 56,79 persen di SMK negeri dan 57,49 persen di SMK swasta.

Pemberian bantuan dana BOS pada SMA/ SMK banyak berpengaruh terhadap aktivitas sekolah baik dalam aktivitas pembelajaran maupun kegiatan ekstrakurikuler. Sekolahsekolah yang semula minim aktivitas baik pada SMA maupun SMK semenjak adanya BOS semakin banyak aktivitas. Hal ini dikemukakan oleh kepala sekolah dalam forum FGD yang menyatakan bahwa BOS SM terbukti efektif dalam peningkatan pembelajaran baik kegiatan kurikuler maupun ekstrakurikuler. Untuk kegiatan kurikuler dana BOS dapat membantu pengadaan buku kurikulum, pengadaan buku teks pelajaran, dan evaluasi pembelajaran. Untuk kegiatan ekstrakurikuler dana BOS membantu penyelenggaraan kegiatan ekstrakurikuler, seperti kegiatan olahraga, kerohanian, pramuka, paskibra, Palang 
Merah Remaja (PMR), dan Usaha Kesehatan Sekolah (UKS).

\section{SIMPULAN DAN SARAN}

\section{Simpulan}

Pemanfaatan dana BOS SM sudah diatur dalam buku petunjuk teknis pelaksanaan BOS yang dikeluarkan oleh Direktorat terkait dan berlaku secara umum. Komponen pemanfatan dana BOS terdiri dari 15 komponen. Pemanfaatan dana BOS SM periode Januari s.d. Desember 2014 antara SMA dan SMK baik yang negeri maupun swasta cukup beragam. Penggunaan dana BOS periode Januari s.d. Desember 2014 terbesar di SMA negeri adalah pada komponen biaya pengadaan buku teks pelajaran sebesar $21,86 \%$ dan pengadaan buku kurikulum 2013 sebesar 20,40\%. Komponen ini merupakan biaya terbesar karena dana BOS diprioritaskan untuk mendukung pelaksanaan kurikulum 2013.

Untuk SMA swasta penggunaan dana BOS pada periode Januari s.d. Desember 2014 terbesar pada komponen penyelenggaraan kegiatan pembinaan siswa/ekstrakurikuler sebesar $17,09 \%$ dan diikuti oleh pengadaan buku teks pelajaran dan pengadaan buku kurikulum 2013 masing-masing sebesar $14,19 \%$ dan $12,76 \%$. Besarnya alokasi dana BOS untuk penyelenggaraan kegiatan pembinaan siswa/ekstrakurikuler di SMA swasta karena alokasi untuk komponen biaya operasional lainnya dibiayai dari sumber lain, seperti iuran komite.

Adapun untuk SMK negeri dan SMK swasta penggunaan dana BOS pada periode Januari s.d. Desember 2014 relatif sama besar. Komponen terbesar yaitu untuk pengadaan bahan habis pakai pada SMK negeri sebesar 21,48 persen dan pengadaan bahan habis pakai pada SMK swasta sebesar 25,04 persen. Komponen tersebut umumnya digunakan untuk kegiatan praktik siswa. Sementara untuk pengadaan buku kurikulum 2013 di SMK negeri dan SMK swasta relatif kecil (5,52 persen dan 4,07 persen) karena buku-buku kurikulum 2013 untuk SMK belum seluruhnya selesai dicetak.

Komponen penggunaan dana BOS terbesar periode Januari s.d. Juni 2015 di SMA negeri dan SMA swasta relatif sama, yaitu pada komponen penyelenggaraan kegiatan pembinaan siswa/ekstrakurikuler dan komponen pemeliharaan dan perbaikan rusak ringan sarana/prasarana sekolah. Pengadaan buku kurikulum 2013 dan buku teks pelajaran proporsinya lebih kecil, karena pengadaan buku-buku tersebut sebagian besar telah dipenuhi pada tahun 2014. Sementara untuk SMA swasta tidak mengalokasikan pengadaan buku kurikulum mengingat sekolah tersebut menunda atau menghentikan pelaksanaan kurikulum 2013 sebagaimana mengikuti anjuran Kemendikbud yang memperkenankan sekolah menunda implementasi kurikulum 2013. Alokasi dana nampaknya dialihkan untuk pengadaan buku teks pelajaran sehingga pada tahun 2015 proporsinya cukup besar, yaitu sebesar 16,86 persen. Proporsi pada komponen penyelenggaraan evaluasi pembelajaran cukup besar di semua satuan pendidikan baik negeri maupun swasta, hal ini disebabkan karena sekolah menyiapkan dan menyelenggarakan ujian baik ujian sekolah, ujian praktik maupun ujian nasional.

Seperti halnya pada tahun 2014, alokasi dana untuk komponen pengadaan alat habis pakaidan pengadaanbahanhabis pakaidiSMK 
negeri dan swasta periode Januari s.d. Juni 2015 cukup besar, yakni antara 9,54\% sampai $28,04 \%$. Selain itu, penggunaan terbesar berikutnya pada komponen pemeliharaan dan perbaikan rusak ringan sarana/prasarana sekolah, yakni lebih dari 13\%.

Pemberian bantuan dana BOS terkait dengan peningkatan mutu pembelajaran di SMA/SMK diakui banyak berpengaruh terhadap aktivitas sekolah baik dalam aktivitas pembelajaran maupun kegiatan ekstrakurikuler. Sekolah-sekolah yang semula minim aktivitas baik pada SMA maupun SMK semenjak adanya BOS semakin banyak aktivitas. Hal ini dikemukakan oleh kepala sekolah dalam forum Focus Group Discussion (FGD) yang menyatakan bahwa BOS SM terbukti efektif dalam peningkatan pembelajaran baik kegiatan kurikuler maupun ekstrakurikuler.

\section{Saran}

Panduan BOS agar lebih jelas, rinci dan mudah dipahami oleh penggunanya, yaitu sekolah. Panduan juga segera diberikan kepada sekolah-sekolah dan diberikan sosialisasi pemanfaatan dana BOS sebelum pelaksanaan BOS dimulai. Pencairan dana BOS agar dapat diupayakan tidak terlambat dalam pengirimannya setiap tahunnya.

Amanat Undang-Undang Nomor 20 Tahun 2003, tentang Sistem Pendidikan Nasional bahwa pendidikan menjadi tanggung jawab, pemerintah, pemerintah daerah, dan masyarakat. Mengingat masih kecilnya sumbangan pemerintah kabupaten/kota dan pemerintah provinsi terhadap pembiayaan operasional sekolah maka diharapkan agar pemerintah kabupaten/kota dan provinsi dapat meningkatkan bantuan dana, untuk memperkecil beban orang tua menyekolahkan anaknya di sekolah menengah.

Penggunaan dana BOS direkomendasikan kepada sekolah agar menyusun prioritas kebutuhan dana, termasuk pembayaran guru honorer, kemudian memasukkan dalam peta sumber dan peruntukannya. Pemetaan sumber dan peruntukan dilakukan terhadap sumber BOS pusat dan bantuan pendanaan dari pemerintah provinsi dan kabupaten/kota yang sudah jelas peruntukannya. Sisanya diajukan kepada komite sekolah untuk dicarikan dananya dari orang tua.

Selanjutnya, mengingat bahwa tujuan lain dari penyediaan dana BOS oleh pemerintah pusat adalah untuk meningkatkan mutu pendidikan di SMA dan SMK, dan bahwa besarnya dana BOS akan ditingkatkan terus sampai berhasil menutup semua pembiayaan operasional sekolah maka sekolah direkomendasikan dapat menerapkan disiplin penggunaan anggaran BOS sesuai peruntukannya. Dengan keinginan sekolah untuk selalu meningkatkan mutu layanannya, apabila disiplin penggunaan anggaran ini dibiasakan maka mutu pendidikan di sekolah akan meningkat.

Laporan pelaksanaan program BOS bersama-sama dengan pemantauan dari dinas pendidikan dan direktorat merupakan salah satu mekanisme identifikasi masalah yang untuk kemudian diusahakan pemecahannya. Mengingat format laporannya tidak berubahubah dan pengirimannya dapat dilakukan melalui internet maka sekolah untuk segera mengisi format-laporan tersebut dengan kekaitan yang dilakukan. Agar BOS dilaksanakan dengan lancar, sekolah direkomendasikan untuk menyusun dan mengirimkan laporan tepat waktu. 


\section{PUSTAKA ACUAN}

Balitbang Kota Medan. 2012. Kajian Efektivitas Pemberian Dana BOS Tingkat SD dan SMP Negeri di Kota Medan Tahun Anggaran 2012. Medan.

Badan Pusat Statistik (update 2017), Angka Partisipasi Kasar Menurut Propinsi tahun 2011-2016 https://www.bps.go.id/linkTableDinamis/view/id/1050 diunduh pada tanggal 16 Mei 2017.

Cenik, I Wayan, A.A. Gede Agung dan I Made Yudana. 2014. Efektivitas Program BOS SMA di SMA Negeri Kabupaten Karangasem dalam Rangka Mendukung Pendidikan Menengah Universal. e-Journal Program Pascasarjana Universitas Pendidikan Ganesha, Singaraja.

Departemen Pendidikan Nasional, 2009. Buku Panduan Bantuan Operasional Sekolah (BOS) untuk pendidikan gratis dalam rangka Wajib Belajar 9 Tahun. Jakarta: Direktorat Jenderal Manajemen Pendidikan Dasar dan Menengah.

Erwantosi. 2010. Analisis Efektivitas, Akuntabilitas dan Transparansi Bantuan Operasional Sekolah pada Sekolah Menengah Pertama di Kota Padang. Padang. ok

Ferdiansyah, Fani. 2013. Sindonews.com https://daerah.sindonews.com/read diunduh pada tanggal 15 Mei 2017.

Hamzah, Amriani. 2013. Perilaku Organisasi. Makasar: Universitas Negeri Makasar. ok

Hidayat. 1986. Teori Efektifitas Dalam Kinerja Karyawan. Yogyakarta: Gajah Mada University Press.

Jayatri, Monika. 2012. Analisis Pengelolaan Dana Bantuan Operasional Sekolah (BOS) di SMPN 11 Yogyakarta dan SMPN 1 Purworejo. Skripsi, Universitas Indonesia.

Kementerian Keuangan. 2004. Peraturan Menteri Keuangan Nomor 54/PMK/07/2014 tentang Peta Kapasitas Fiskal Daerah. Jakarta.

Kementerian Pendidikan dan Kebudayaan. 2014. Petunjuk Teknis Bantuan Operasional Sekolah (BOS). Jakarta: Direktorat Pembinaan Sekolah Menengah Atas, Dikdasmen.

Kementerian Pendidikan Nasional. 2009. Peraturan Menteri Pendidikan Nasional Nomor 69, Tahun 2009 tentang Standar Biaya Operasi Nonpersonalia Tahun 2009 Untuk Sekolah Dasar/Madrasah Tsanawiyah (SMP/MTs), Sekolah Menengah Atas/Madrasah Aliyah (SMA/MA), Sekolah Menengah Kejuruan (SMK), Sekolah Dasar Luar Biasa (SDLB), Sekolah Menengah Pertama Luar Biasa (SMPLB), dan Sekolah Menengah Atas Luar Biasa (SMALB). Jakarta.

Kementerian Pendidikan dan Kebudayaan. 2014a. Petunjuk Teknis Bantuan Operasional Sekolah (BOS). Jakarta: Direktorat Pembinaan Sekolah Menengah Kejuruan, Dikdasmen.

Kementerian Pendidikan dan Kebudayaan. 2014b. Kajian Pelaksanaan BOS Jenjang Pendidikan Menengah. Jakarta: Pusat Penelitian Kebijakan Pendidikan dan Kebudayaan.

Komaruddin. 1994. Ensiklopedia Manajemen. Bumi Aksara. Jakarta.

Kurniasari, Risca, Kurniasari Agus Sugiono, Andiana, Taufik Kurrohman. 2015. Pengaruh Ketepatan Dana, Kecukupan Dana dan Sasaran Penggunaan Dana Bantuan Operasional Sekolah Terhadap Peningkatan Prestasi Belajar Siswa Di Kabupaten Jember. E-Journal Ekonomi Bisnis dan Akuntansi, 2015 Volume 2. 
Kurniawan, Agung. 2005. Transformasi Pelayanan Publik. Yogyakarta: Pembaruan.

Martani dan Lubis. 1987. Teori Organisasi. Bandung: Ghalia Indonesia.

Republik Indonesia. 2008. Peraturan Pemerintah Nomor 48 Tahun 2008 tentang Pendanaan Pendidikan. Jakarta.

Republik Indonesia. 2003. Undang-Undang Republik Indonesia Nomor 20 Tahun 2003 tentang Sistem Pendidikan Nasional. Jakarta.

Siagian, Sondang P. 2001. Manajemen Sumber Daya Manusia. Jakarta: Bumi Aksara. ok

Steers, Richard. 1985. Efektivitas Organisasi. Jakarta: Erlangga.

Waluyo Bagus dan Rostoyo Hartarto P. 2012. Efektivitas Manajemen Dana Bantuan Operasional Sekolah (BOS) Dalam Meningkatkan Mutu Pendidikan (Studi Kasus Pengelolaan Dana BOS di SDN Pacarkeling 1 Surabaya). 